\title{
Implementation of Competence-Based Approach: Stories of Practices and the Tuning contribution to academic innovation*
}

\author{
Anna Serbati**
}

doi: 10.18543/tjhe-3(1)-2015pp19-56

\begin{abstract}
The rationale of the present paper is to investigate and stimulate a reflection on the Tuning contribution to academic innovation through the collection of case studies among some Tuning projects, focussing on methods and tools to implement successful and innovative approaches to learning, teaching, and assessment appropriate for competence-based approach (CBA). In order to deepen these concepts, a conceptual framework on competence-based approach and student-centred learning will be presented, particularly focussing teacher conceptions of teaching as well as pedagogical content knowledge and their influence on teaching practices. The Tuning contribution in supporting academic innovation will then be deepened, through a macro-level overview of the methodology, and a synoptic table of cross-cutting themes identified across the Tuning projects will be the starting point of the empirical part of this study. Moreover, the multiple case studies conducted through semi-structured interviews with teachers from Higher Education Institutes involved in previous completed Tuning projects will be presented. Research design, sampling and data analysis will be described, and major findings will be presented. Results show a general understanding, but with different perspectives on the competence based approach as well as appropriate teaching and learning methods applied worldwide within the CBA framework. Outlines on the Tuning contribution to academic innovation in this framework will be offered, by identifying main strengths, weaknesses, threats and opportunities of the methodology. Suggestions and guidelines for future projects, training and researches of the Tuning Academy are provided for possible implementation, highlighting the relationship between teaching, learning and research.
\end{abstract}

Keywords: Competence-based learning; teaching and learning activities; Tuning contribution; research; training; academic community; practice sharing.

* This work was carried out at Deusto International Tuning Academy (DITA) at the University of Deusto, Bilbao, Spain, ans was financially supported by DITA Short-Term Visit Scholarship (http://tuningacademy.org/short-term-visits-call/). The Author would like to thank participants for their time and availability, deep and precious reflections.

** Dr. Anna Serbati (anna.serbati@gmail.com) is currently research associate at the Department of Philosophy, Sociology, Education and Applied Psychology at the University of Padova (Italy). Her research focuses on Adult Learning and Higher Education. 


\section{Conceptual framework of competence-based approach and student-centred learning}

Historically, the University has always been a place for high level research that can contribute to the development of scientific progress and human wellbeing. However, with the expansion and massification of the higher education sector, the importance of research is combined with a larger focus on teaching and students' demands for quality teaching. Therefore, Universities have been called to reconsider their priorities and the services offered to the students. Teaching practice itself is changing, faced with international communities of students, young and mature, connected with all sources of online information and materials and with increasing level of competition among institutions. New pedagogical methods are emerging in order to reply to new challenges for higher education. New reflections are coming up from faculty towards a more integrated professional identity, through the reconceptualization of the relationship between teaching, learning and research. ${ }^{1}$

In this connection, Gibbs ${ }^{2}$ stated that "the notion that teaching excellence flows directly from research excellence is absurd: they are in direct conflict, compete for academics attention and only one of them is rewarded". In literature this is a controversial issue. However it can be noticed that there is a general growing attention to the teaching practice and towards adopting methodologies that enhance a learner-centred approach. Moreover, as Etzkowitz \& Viale $^{3}$ suggest, there are many emergent polyvalent research fields with theoretical, technological and commercial potential at the same time. The consequential process that goes from theory to practice - which used to predominate in the past - is now becoming a more integrated process, in which there is a mutual reinforcement between the two and a more evident interdisciplinarity, as Delanty ${ }^{4}$ and Gibbons et al. ${ }^{5}$ highlight.

${ }^{1}$ Marianne Bauer and Mary Henkel, M, "Responses of Academe to Quality Reforms in Higher Education: A Comparative Study of England and Sweden", Tertiary Education and Management, 3 (3) (1997): 211-228. DOI: 10.1007/BF02679385.

2 Graham Gibbs, "The Relationship between Quality in Research and Quality in Teaching",QualityinHigherEducation, 1(2)(1995): 147-157.DOI: 10.1080/1353832950010205.

${ }^{3}$ Henry Etzkowitz and Riccardo Viale, "Polyvalent knowledge and the entrepreneurial university: A third academic revolution?" Critical Sociology 36(4) (2010): 595-609. DOI: 10.1177/0896920510365921.

${ }^{4}$ Gerard Delanty, "The university and modernity: A history of the present" In The Virtual University? Knowledge, markets and management, ed. Robins K, Webster F (Oxford: Oxford University Press 2002), 31-48.

${ }^{5}$ Michael Gibbons, et al.. The New Production of Knowledge.(London: Sage Publications, 1994). 
With the Bologna Process in Europe since 1999 Universities have been asked to rethink the entire educational system. New aspects became more and more relevant, such as mobility, social dimension of higher education, employability, synergies among research, education innovation and studentcentred learning. ${ }^{6}$ Regarding the last point, according to a constructivist approach, teacher methods should emphasize the active role of students in the learning processes, encouraging appropriate learning activities to foster a deep approach to learning, instead of a surface approach to it ${ }^{7}$. Bligh ${ }^{8}$ widely discussed that lectures are less effective than many other teaching methods for achieving almost every educational goal. His studies demonstrated that they can be effective in transmitting information, however, they are ineffective in promoting independent thought because students are not actively engaged and don't stimulate student enthusiasm in a subject. Following this line, Gibbs ${ }^{9}$ argues that studies of the quality of student attention during lectures, of the accuracy and comprehensiveness of his/her notes taken during lectures, reach to the conclusion that lectures may be cheap ways of teaching, but not effective ones.

Entwistle ${ }^{10}$ offered an interesting conceptual framework that includes both teacher's and leaner's roles in the teaching and learning process and considers as relevant variables the content as well as the learning environment. This framework suggests, therefore, that quality learning can be achieved when learners and teachers together deal with content in pedagogically suitable ways. ${ }^{11}$ On the students' side, prior knowledge and abilities should be considered, as well as their attitude and behaviours in approaching studying and learning and perceiving the learning environment. On the teachers side, it is relevant to take into account the design of the intended learning outcomes and the consistency with the teaching materials, methods as well as the features of the created learning environment, all

${ }^{6}$ Henry Etzkowitz, Marina Ranga, and James Dzisah "Whither the university? The Novum Trivium and the transition from industrial to knowledge society", Social Science Information 51(2) (2012): 143-164. DOI: 10.1177/0539018412437099.

7 John Biggs and Catherine Tang, Teaching for Quality Learning, (New York, McGrawHill, 2007).

8 Donald Bligh, What's the Use of Lectures? (London: Jossey-Bass, 2000).

${ }^{9}$ Graham Gibbs, 53 Powerful Ideas All Teachers Should Know About, idea n. 20, Ocober 2014, available at: http://www.seda.ac.uk/53-powerful-ideas/

${ }_{10} \mathrm{Neol}$ Entwistle, Concepts and conceptual frameworks underpinning the ETL project. Occasional Report 3, Enhancing teaching-learning environment (2003).

${ }^{11}$ Nick Zepke, "Threshold concepts and student engagement: Revisiting pedagogical content knowledge", Active Learning in Higher Education 14(2) (2013). DOI: 97-107, DOI: $10.1177 / 1469787413481127$. 
influenced by their conceptions and beliefs of teaching. Since the focus of the present paper is mainly on practices of teaching according to the competence-based approach, the teachers' part of the model particularly draws the attention: the two aspects related to content /subject knowledge on one hand, and teaching/pedagogical experience and ideas on the other hand, are interpreted in an integrated way, as proposed by Shulman ${ }^{12}$ with the so-called concept pedagogical content knowledge. According to Entwistle $^{13}$ there are many variables to be considered (see figure 1) in interpreting a teaching practice, and these refer both to the discipline and to the pedagogical knowledge in an integrated way. Core elements affecting ways of thinking and practising in the subject (WTPs) are the teacher conceptions of teaching. ${ }^{14}$ The literature on teaching in higher education developed specific research fields concerning teachers' conceptions of teaching in higher education. Teacher-centered approaches and studentcentered ones might be considered as a continuum of teachers' orientations. Teacher-centered approaches interpret teaching as knowledge transmission from the experts (teachers) to students, whose knowledge is not considered as relevant for learning. Student-centered approaches consider transmission as one component of the whole process, but the major focus is on students' learning and therefore he/she has a key role in creating a learning environment. Each student develops individual habits in studying, and these can be congruent or dissonant $\mathrm{t}^{15}$ with the demands of the learning environment. Teachers who follow student-centered approaches need to consider the relation between learning styles, students' existing knowledge and facilitate students' reflection, critical elaboration, and knowledge application to different situations.

As mentioned, due to the complexity of the teaching phenomenon, many variables have to be considered, depending on the context, the subject, the local regulations and the cultural conception of higher education.

${ }^{12}$ Lee S. Shulman, "Knowledge and teaching: Foundations of the new reform". Harvard Educational Review 57(1) (1987): 1-22.

${ }^{13}$ Neol Entwistle, Concepts and conceptual frameworks underpinning the ETL project. Occasional Report 3, Enhancing teaching-learning environment (2003).

${ }^{14}$ See: Lyn Gow and David Kember, "Conceptions of teaching and their relationship to student learning," British Journal of Educational Psychology 63(1993): 20-33; David Kember, "Teaching beliefs and their impact on students' approach to learning," in Teaching and Learning in Higher Education, ed. Barry Dart and Gillian Boulton-Lewis, 1-25 (Camberwell, Australia: Australian Council for Educational Research, 1998).

15 Jan D. Vermunt and Nico Verloop, "Congruence and friction between learning and teaching”. Learning and Instruction, 9, (1999): 257-280. DOI: http://dx.doi.org/10.1016/ S0959-4752(98)00028-0. 
Samuelowicz and Bain ${ }^{16}$ highlighted that teachers from different disciplines have acquired different conceptions of teaching because they experienced different epistemological conceptions of teaching as well as diverse processes of socialisation. Their beliefs about teaching are indeed different and influenced by the nature of the subject they teach. Moreover, professors do not act as individual professionals but are embedded in an institutional context, which may be relevant or at least influential in teachers' conceptions and actions. ${ }^{17}$ In this multilevel framework, each teacher finds strategies to design course materials and learning environments to allow students achieving the expected learning outcomes.

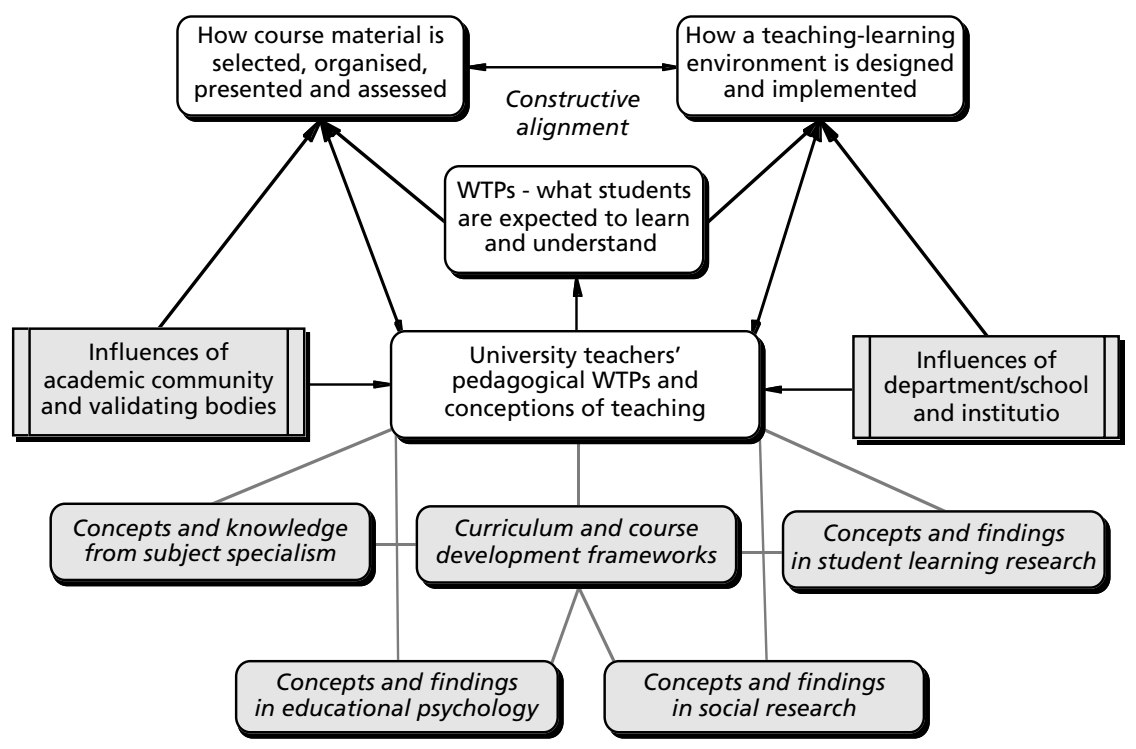

Figure 1

Influences on teaching and pedagogical ways of teaching and practicing in the subject

Source: Slightly adapted from Entwistle. ${ }^{18}$

${ }^{16}$ Katherine Samuelowicz and John D. Bain, "Conceptions of teaching held by academic teachers", Higher Education, 24, (1992): 93-111.

17 Jenny J.Lee., "The shaping of the departmental culture: Measuring the relative influences of the institution and discipline", Journal of Higher Education Policy and Management 29 (1) (2007): 41-55, DOI: 10.1080/13600800601175771

${ }_{18}$ Entwistle, Concepts and conceptual frameworks underpinning the ETL project, 5. 
Baeten, Struyven and Dochy ${ }^{19}$ in their literature review state that studentcentred teaching methods are related to three main components:

- An active involvement of the students: they are asked to construct knowledge by selecting, interpreting and applying information. Their assignments require reflections and constructions of their point of view on the subject.

- The role of teacher switching from transmitter to facilitator, who helps students out with problems they may face without telling the solutions.

- The learning and assessment activities which are "authentic assignments", such as practical and complex case studies.

Moreover, learning goals may be achieved in class through individual work and, therefore, individual reward, and also in a cooperative way, which according to Slavin ${ }^{20}$ "refers to classroom techniques in which students work on learning activities in small groups and receive rewards or recognition based on their group's performance."

A deep approach to learning, supported by the above mentioned teaching strategies, as well as students' self-regulation and intrinsic motivation are framed in an active learning and constructivist approach, which aims at creating conditions for students to develop competences. ${ }^{21}$ All teaching approaches that use competences as a starting point for determining the goals and contents of education could be called competence-based education. After the Bologna Process, this represents the major framework that universities have introduced with the aim of creating a European Higher Education Area (EHEA) ${ }^{22}$ and to reinforce dialogue and a common language between education and labour market. The term "competence" has been largely debated and still can have very different meanings ${ }^{23}$ depending on the author

${ }^{19}$ Marlies Baeten, Katrien Struyven, Filip Dochy, "Student-centred teaching methods: Can they optimise students' approaches to learning in professional higher education?", Studies in Educational Evaluation 39 (2013): 14-22. DOI: http://dx.doi.org/10.1016/j.stueduc.2012.11.001

${ }^{20}$ Robert E. Slavin, "Cooperative learning”. Review of Educational Research 50(2) (1980): 315-342. DOI: 10.3102/00346543050002315

${ }^{21}$ Marcel Van der Klink, Jo Boon, Kathleen Schlusmans, "Designing and Implementing Views on Competencies". In Competencies in Organizational E-Learning: Concepts and Tools, ed. Miguel A. Sicilia (Idea Group, 2007).

${ }^{22}$ Europan Commission. The Bologna Process - reforming universities in the next decade, 22 April 2009. Available at: http://europa.eu/rapid/pressReleasesAction.do?reference $=\mathrm{IP} / 09 / 615 \&$ format $=$ HTML\&aged $=0 \&$ language $=\mathrm{EN} \&=$ guiLanguage $=\mathrm{fr}$

${ }^{23}$ Jean-Claude Coulet, "La notion de compétence: un modèle pour décrire, évaluer et développer les competences", Le travail humain, 74(1) (2011): 1-30. DOI: http://dx.doi. org/10.3917/th.741.0001. 
and discipline. However, the research of the last years illustrates some key elements of the concept itself, both from objectivist approaches and constructivist ones. Kiffe and Guy ${ }^{24}$ in their review of international literature recently pointed out that a competence is, first of all, situational, namely referred to one or more situations where it is mastered in situ, as an aptitude to mobilise a set of appropriate resources in a relevant manner in order to deal successfully with problem situations. ${ }^{25}$ Competences should be assessed and, therefore, standard criteria are required in order to evaluate whether a performance has been successful or not. In fact, since competence is not visible itself, it must be observed through measurable behaviours (learning outcomes).

Literature offers a wide range of definitions of the concept of competence. As von Glaserfeld ${ }^{26}$ suggested, a key element in a constructivist approach to competence is the viability of the definition. As stated by Stoof et al. ${ }^{27}$ the definition is a collective activity, which involves different people trying to reach an inter-subjective agreement. Moreover, the definition selected should be appropriate for the goal, especially if it is a working definition, and take into account the context of its use (human resources management, construction of educational programmes, staff development design, recruitment or change management, etc.). These authors highlight difference forces composing a competence, both from an inside approach and from an outside one, that are relevant to having a broad picture of the phenomenon. As for the first aspect, five dimensions might be considered: the opposition between personal versus task characteristics, with a major focus on personal characteristics of the persons who do the job or achievement required. Another opposition is between individual versus distributed competence, which refers to interpreting the competence as something that belongs to a single person or to a group of people/ team in a shared perspective. A further dualism is between specific versus general competence, namely between a competence with a focus on a particular subject or discipline or another with a more open focus to transversal elements

${ }^{24}$ Kiffer Sacha and Tchibozo Guy, "Developing the Teaching Competences of Novice Faculty Members: A Review of International Literature", Policy Futures in Education 11(3) (2013): 277-289. DOI: 10.2304/pfie.2013.11.3.277.

${ }_{25}$ Guy Le Boterf, De la compétence: essai sur un attracteur étrange. (Paris: Editions d'Organisation, 1994).

${ }^{26}$ Ernst Von Glaserfeld, "A constructivist approach to teaching” In Constructivism in education (pp). Eds L. Steffe \& J. Gale (Eds.) (Hillsdale, NJ: Lawrence Erlbaum, 1995), 369-384.

${ }^{27}$ Angela Stoof, Rob L. Martens, Jeroen J. G. van Merriënboer, Theo J. Bastiaens, "The Boundary Approach of Competence: A Constructivist Aid for Understanding and Using the Concept of Competence", Human Resource Development Review 1 (3) /2002): 345-365. DOI: $10.1177 / 1534484302013005$. 
which may be appropriate in different contexts. Another opponent pair is between levels of competence versus competence as a level or, in other words, between a wide concept of competence which includes different stages with different requirements (i.e. expert and novice) and a more precise one that represents a stage itself, in between other stages. The last element considered by Stoof et al ${ }^{28}$ are the opponent teachable competence versus non teachable competence, which actually compare a paradigm which states that elements such as skills and knowledge are visible and may be taught with appropriate educational programmes, and a paradigm that interprets the competence as unique combination, that may be not taught itself (only single skills or knowledge are teachable). As for the outside approach, there are a few other concepts such as performance, qualification, ability, knowledge-skills-attitude, expertise that relate to the competence and need a clarification. In this article, the interest is particularly focused on the relationship between competence and qualification. When a person is qualified, it means that there is a guarantee that at least minimal requirement for a job/degree/programme has been reached. It might be assumed that a qualified person is always competent, but it can happen that a qualified person does not seem to be competent, or a competent person is not qualified (for example if learning occurred in informal and non-formal contexts). It becomes, therefore, really important to find strategies and structures for educationalists to design qualifications by clearly describing competences that students should acquire to obtain the qualification and to align ${ }^{29}$ them with the teaching, learning and assessment methods developed to create an appropriate learning environment. In this sense, a relevant contribute is offered by Tuning methodology, which will be discussed in the next paragraph.

\section{Tuning contribution in supporting academic innovation}

Tuning ${ }^{30}$ Educational Structures in Europe Project is an initiative started in 2000 and is still playing a relevant role worldwide to support higher

28 Angela Stoof, Rob L. Martens, Jeroen J. G. van Merriënboer, Theo J. Bastiaens, "The Boundary Approach of Competence: A Constructivist Aid for Understanding and Using the Concept of Competence", Human Resource Development Review 1 (3) /2002): 345-365. DOI: $10.1177 / 1534484302013005$.

${ }^{29}$ See the concept of "constructive alignment" in: John Biggs, Catherine Tang Teaching for Quality Learning. (NY: McGraw-Hill, 2007).

30 Julia González and Robert Wagenaar, TUNING Educational Structures in Europe II. Universities' contribution to the Bologna Process. Final report Project Phase II. Universidad de Deusto / Universiteit Groningen, 2005. 
education institutions in reforming curricula in order to respond to new evolving societies and to prepare workers and citizens of the knowledge society.

As Wagenaar explains ${ }^{31}$ the project was based on some key assumptions: the importance of the full involvement of academics as key players in this process; the development of internationally shared reference points at subject area level; the involvement in the curricula design of (potential) employers and professional organisations through appropriate consultation process; the importance of developing flexible degree programmes and international mobility; the need of common language and glossary among different stakeholders. Regarding the last point, the contribution of Tuning has been relevant in developing the above-discussed concept of competence. Competences in Tuning are dynamic combinations of cognitive and metacognitive skills, knowledge and understanding, interpersonal, intellectual and practical skills, and ethical values and they are developed in all course units and assessed at different stages of a programme. Some competences are subject-area related (specific to a field of studies), while others are generic. ${ }^{32}$ Students develop in their careers an integrated body of knowledge and skills from many different disciplines as well as transferable skills such as problem-solving, critical and creative thinking, communication and leadership skills. In order to determine a competence - which is a complex phenomenonStoof et al. ${ }^{25}$ - and to assess it, Tuning suggests the use of learning outcomes statements, that can determine the level of competence. Indeed, learning outcomes are statements of what a learner is expected to know, understand and be able to demonstrate after completion of a learning experience. In order to deepen the key pillars of the methodology and to prepare the empirical part of this study, the researcher conducted a literature review and comparative analysis of Tuning reports and publications related to major Tuning projects. In order to understand better and represent the Tuning rationale and philosophy and have a macrolevel overview of the methodology, the preliminary outcome of this analysis is a synoptic table of cross-cutting themes (Table 1) found across the Tuning projects.

${ }^{31}$ Robert Wagenaar, "Competences and learning outcomes: a panacea for understanding the (new) role of Higher Education?", Tuning Journal of Higher Education, 1(2) (2014): 279302.

${ }^{32}$ Lokhoff, Jenneke, et al.. A Guide to Formulating Degree Programme Profiles. Bilbao, Groningen, and The Hague: Universidad de Deusto, 2010. 


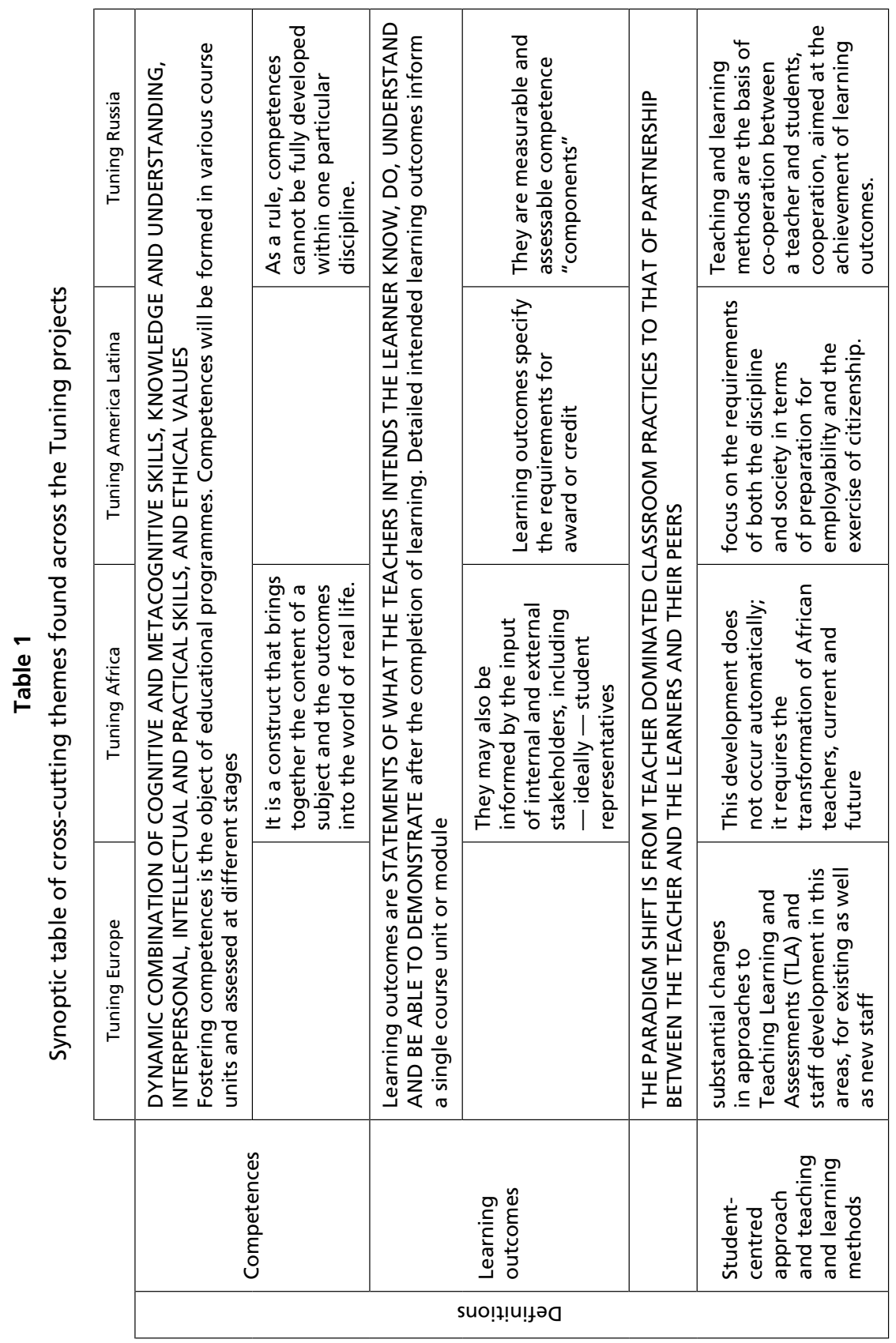




\begin{tabular}{|c|c|c|c|c|}
\hline 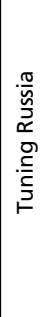 & 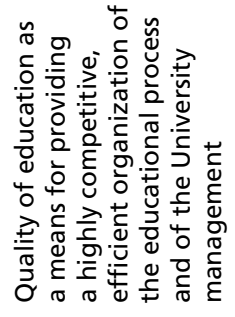 & 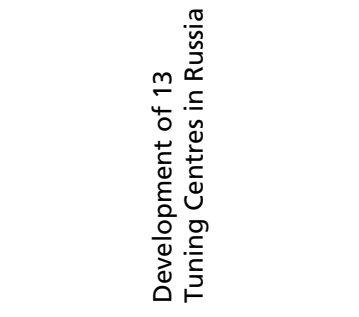 & \multirow{4}{*}{ 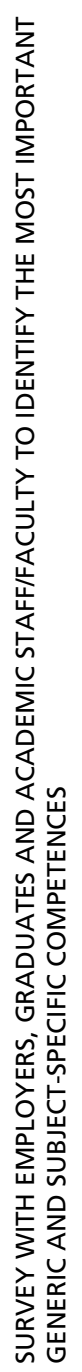 } & \\
\hline 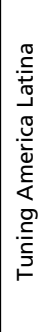 & 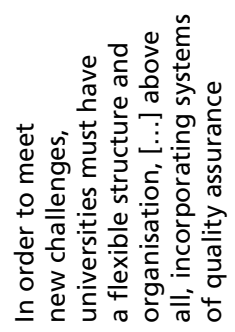 & 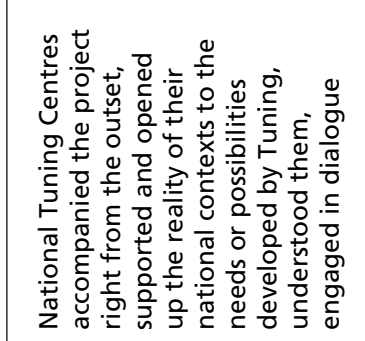 & & 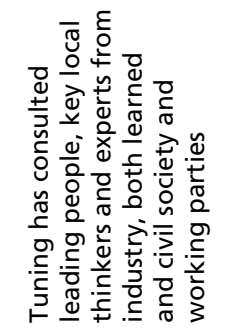 \\
\hline 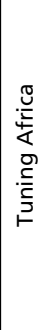 & 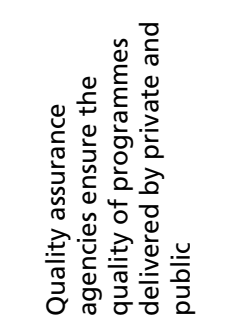 & 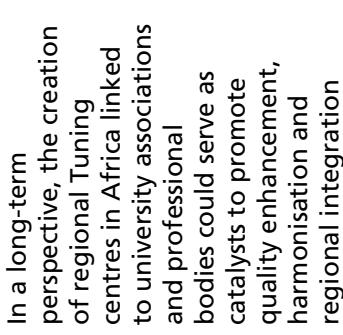 & & 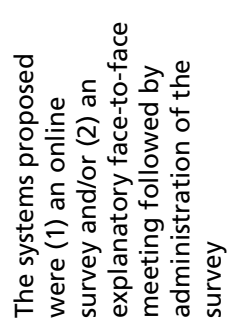 \\
\hline \multirow[t]{3}{*}{ 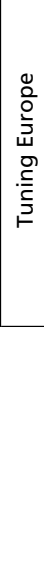 } & 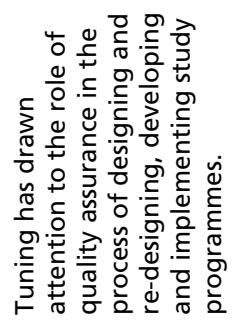 & & & 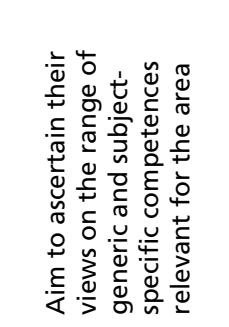 \\
\hline & 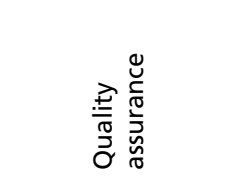 & 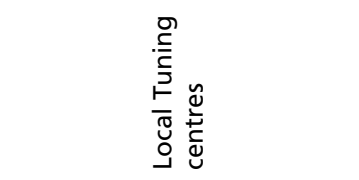 & & 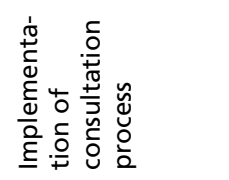 \\
\hline & suo!ฺ!u!łə0 & & & \\
\hline
\end{tabular}

Tuning Journal for Higher Education 


\begin{tabular}{|c|c|c|c|c|c|}
\hline 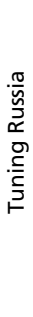 & 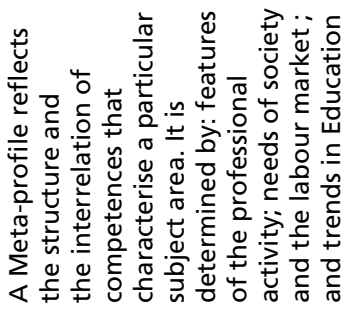 & \multirow{4}{*}{ 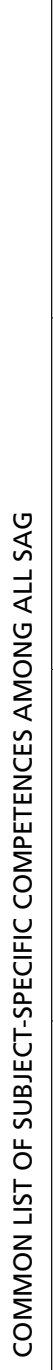 } & \multirow[b]{2}{*}{ 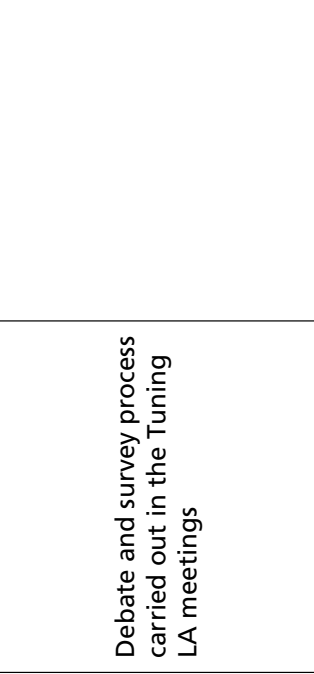 } & \multirow{4}{*}{ 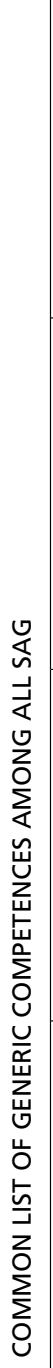 } & \\
\hline 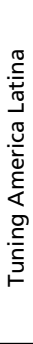 & 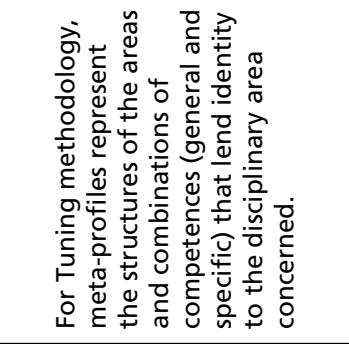 & & & & \\
\hline 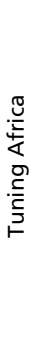 & 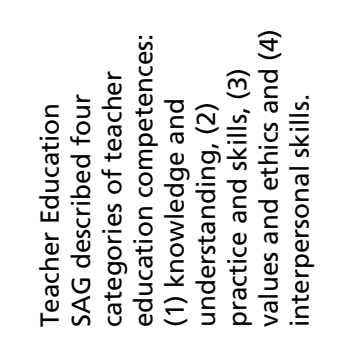 & & 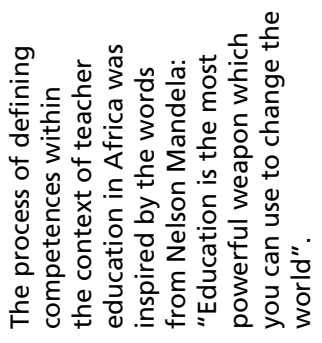 & & \\
\hline 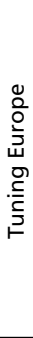 & & & 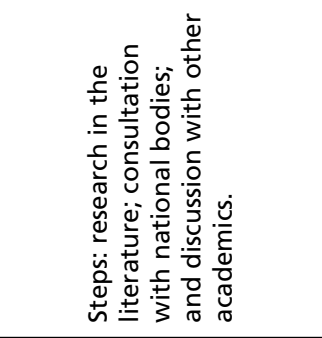 & & 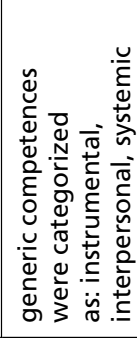 \\
\hline & $\begin{array}{l}\frac{0}{2} \\
\frac{1}{0} \\
0 \\
\frac{0}{1} \\
\frac{1}{0} \\
\stackrel{0}{0} \\
\sum\end{array}$ & & 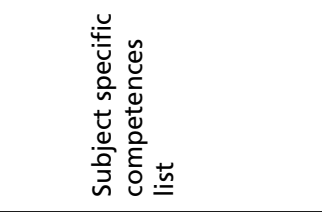 & & 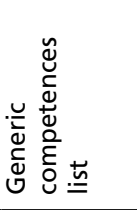 \\
\hline & & & słjnsəy & & \\
\hline
\end{tabular}




\begin{tabular}{|c|c|c|c|c|c|}
\hline 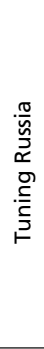 & 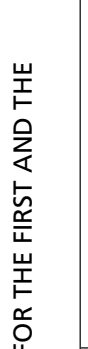 & & 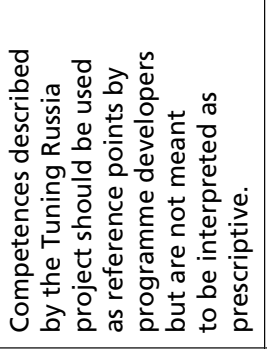 & 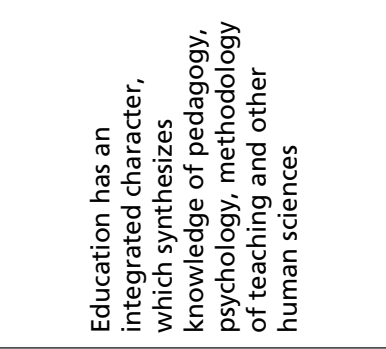 & 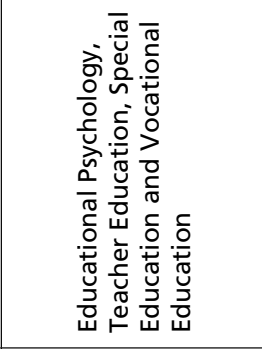 \\
\hline 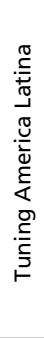 & 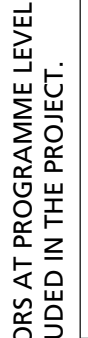 & & 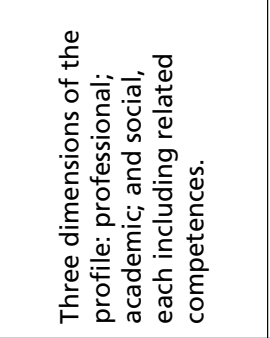 & 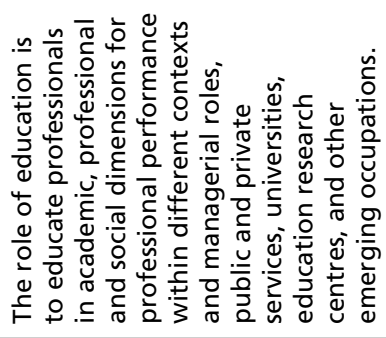 & 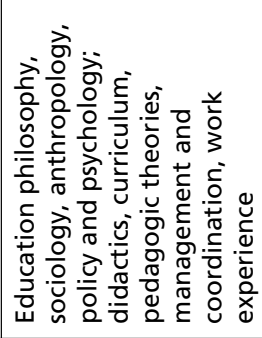 \\
\hline 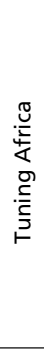 & 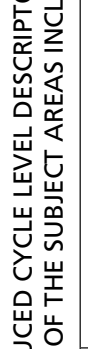 & & 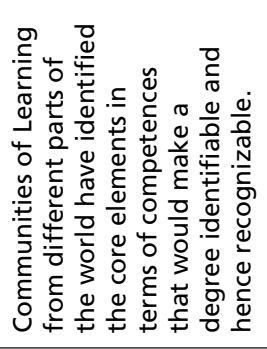 & 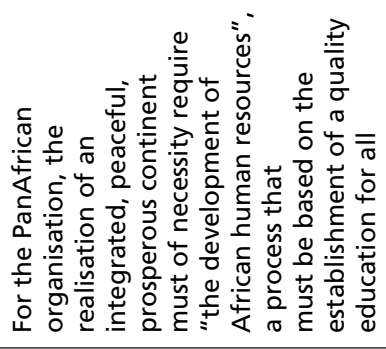 & 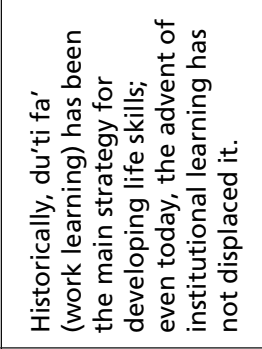 \\
\hline 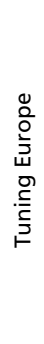 & 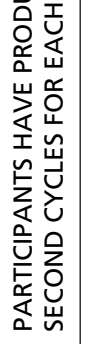 & 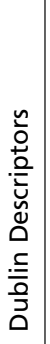 & 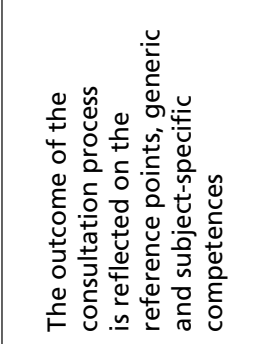 & 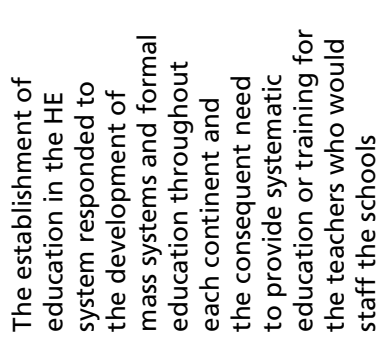 & 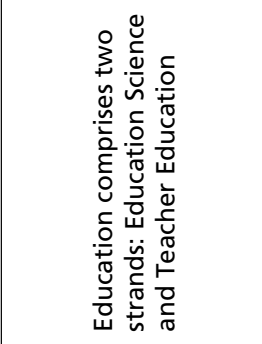 \\
\hline & 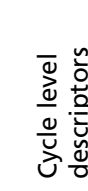 & & 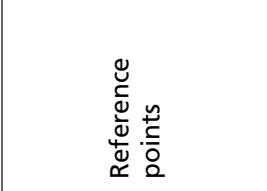 & 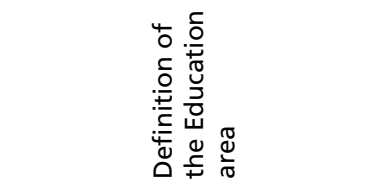 & 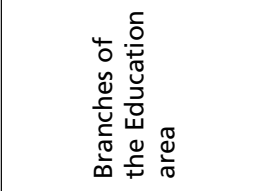 \\
\hline & \multicolumn{3}{|r|}{ Szןnsəy } & \multicolumn{2}{|c|}{ еәд $\forall$ uо!̨еәпрэ } \\
\hline
\end{tabular}

Tuning Journal for Higher Education 


\begin{tabular}{|c|c|c|}
\hline 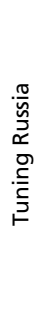 & 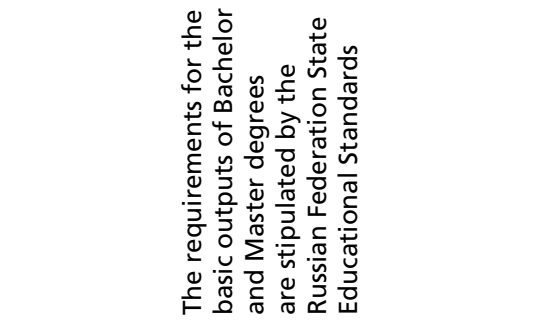 & 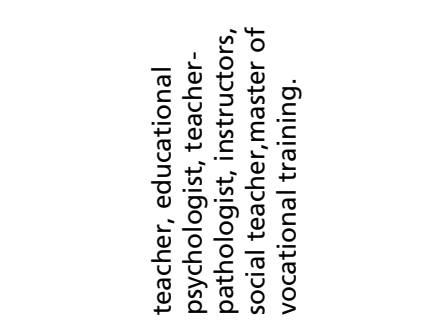 \\
\hline 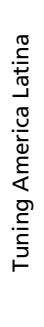 & 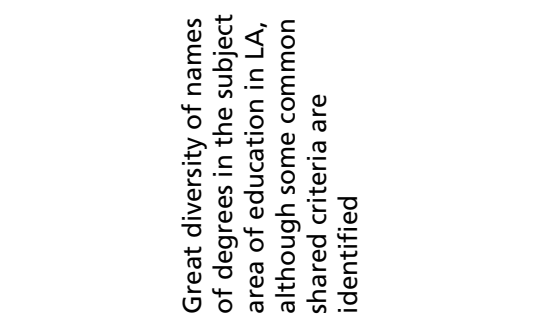 & 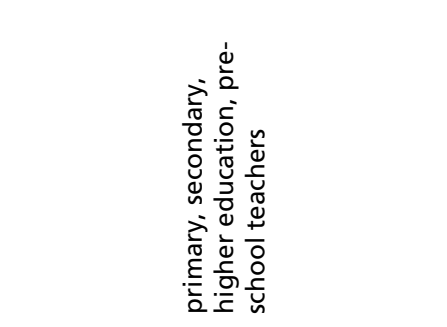 \\
\hline 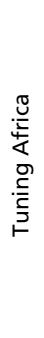 & 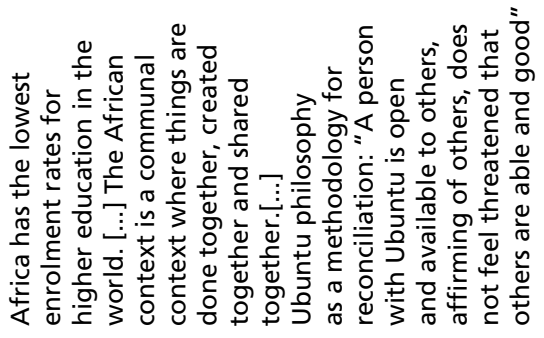 & 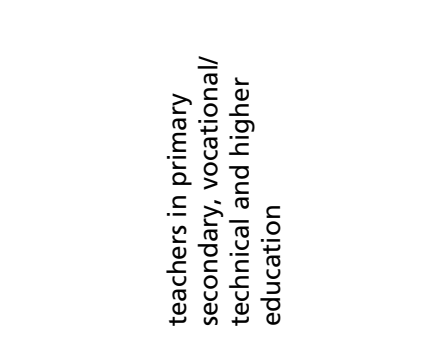 \\
\hline 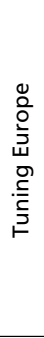 & 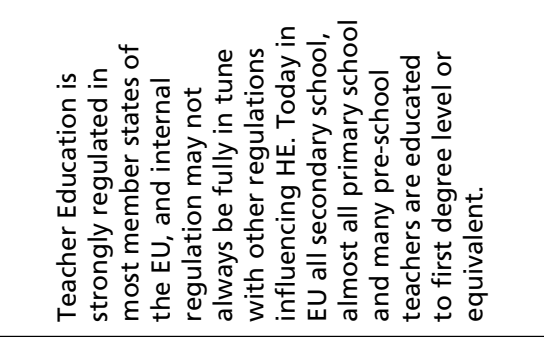 & 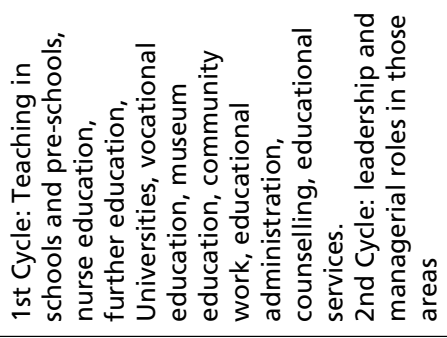 \\
\hline & 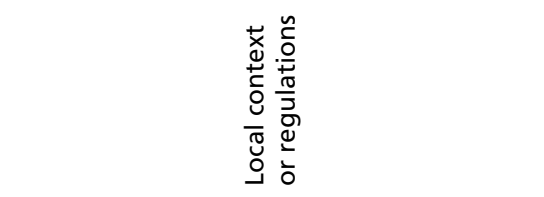 & 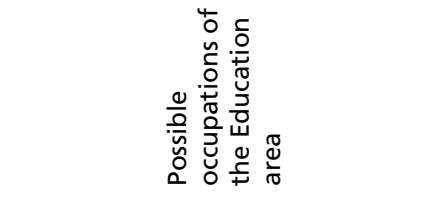 \\
\hline & \multicolumn{2}{|c|}{ еәл $\forall$ ио!̨еэпрэ } \\
\hline
\end{tabular}




\begin{tabular}{|c|c|c|c|}
\hline & 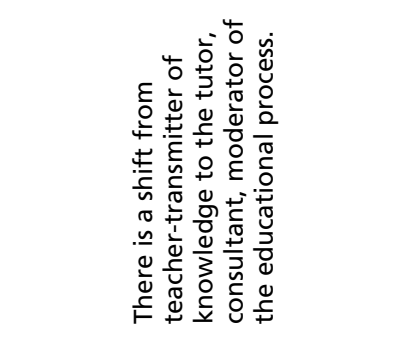 & 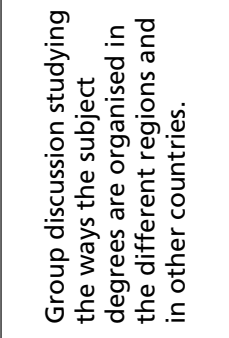 & \\
\hline & 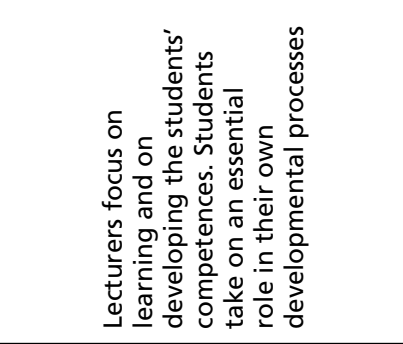 & 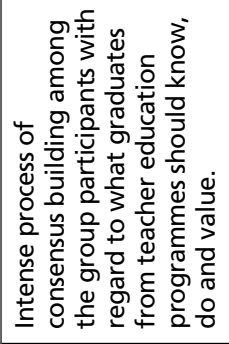 & 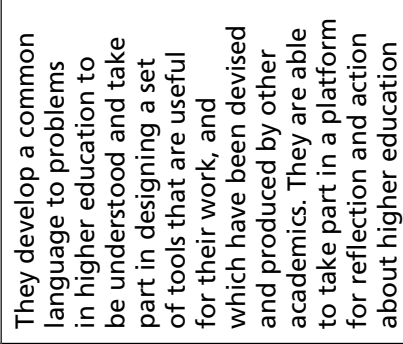 \\
\hline & 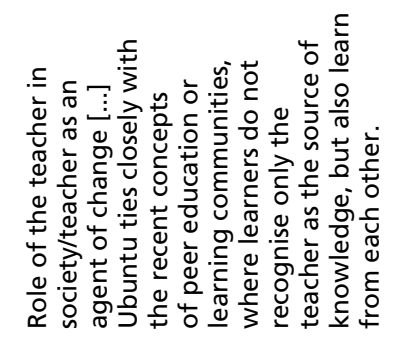 & 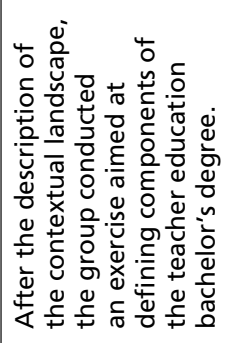 & 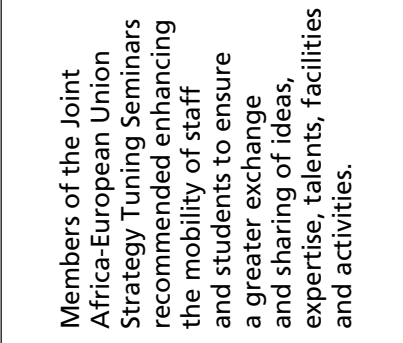 \\
\hline 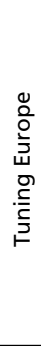 & 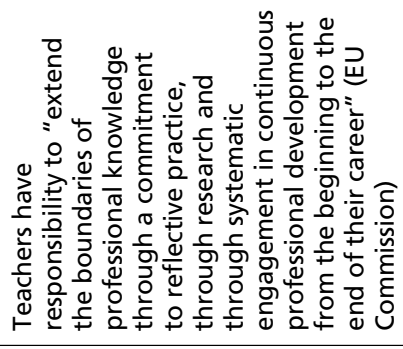 & 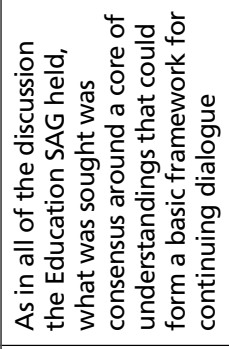 & 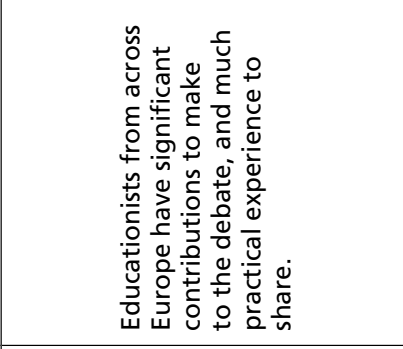 \\
\hline & 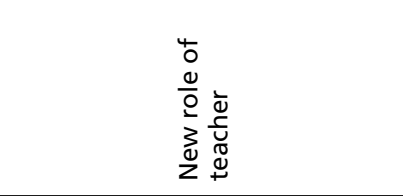 & 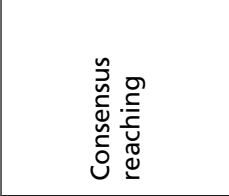 & 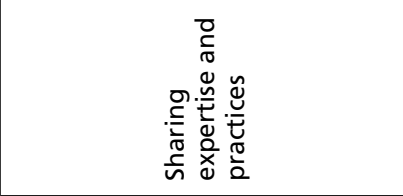 \\
\hline & \multicolumn{3}{|c|}{ sәчวео $\mathrm{ddd}_{\forall}$} \\
\hline
\end{tabular}

Tuning Journal for Higher Education 


\begin{tabular}{|c|c|c|}
\hline 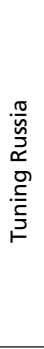 & 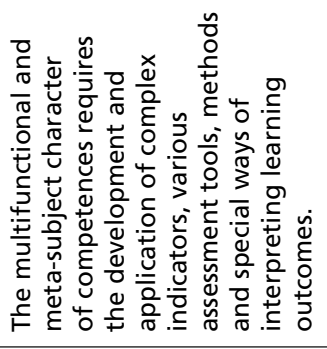 & 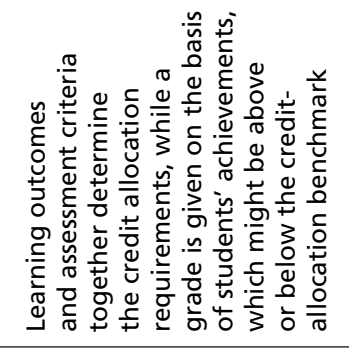 \\
\hline 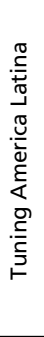 & 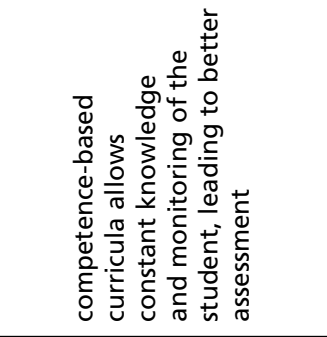 & 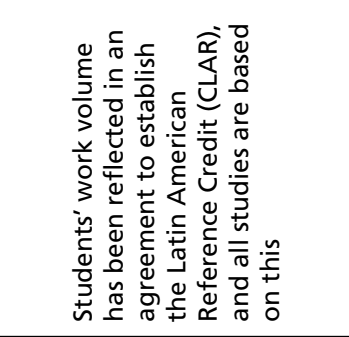 \\
\hline & 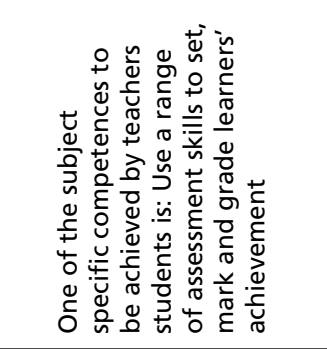 & 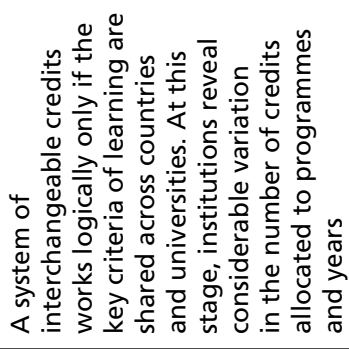 \\
\hline 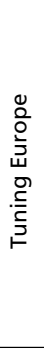 & 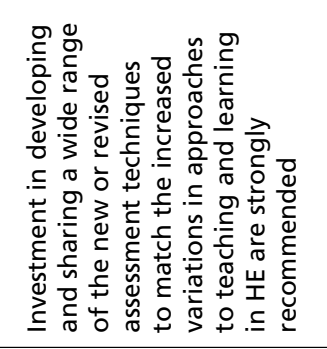 & 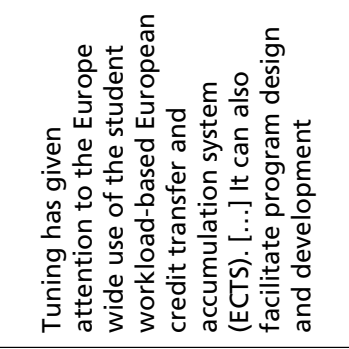 \\
\hline & o & 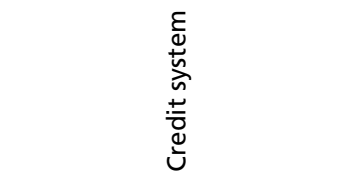 \\
\hline & \multicolumn{2}{|c|}{ sәчวеoıdd $\forall$} \\
\hline
\end{tabular}


The selected projects for this first study phase were the completed Tuning projects carried out so far (not feasibility studies) since it was important to have a deep understanding of the whole development of the methodology and its features: Tuning Europe, Tuning Africa, Tuning Latin America and Tuning Russia. Reports and documents ${ }^{33}$ related to these major projects have been analysed, with a particular reference to the "Education" Subject Area Groups, which are the major area of interest of this study on competence-based learning approach. The synoptic table (Table 1) shows commonalities and differences in definitions, results, features of the education area and approaches among the projects. Whilst not exhaustive, this first part of the study shows major cross-cutting themes relevant for an initial understanding of the methodology to further investigate practices of teaching according to the competence-based approach. The researcher coded themes emerging from the documents and grouped them in categories.

Tuning appears first of all as an opportunity to clarify the terminology, deepening concepts such as competence, learning outcomes, student centred approach and related teaching and learning methods and quality assurance. Across the different projects considered, the majority of the results are similar and common. However, it is clear that there has been an evolution in the philosophy and in implementation. Some key elements as the subjectspecific and generic competences lists, cycle level descriptors, consultation process, Tuning centres - relevant since the very beginning - have been deepened and enhanced with a clearer and shared understanding and enriched by the introduction of new conceptual elaboration such as meta-profile and reference points. Beside the variable "time", it is important to consider the variable "context": Tuning, as a worldwide phenomenon, touched many different countries and regions, and the core methodology has been embedded in the local understanding and structures of educational systems. For this reasons, definitions and branches of Education area, local contexts and regulations, possible occupations of graduates in Education programmes have been mentioned in the table and will be the basis for discovering

${ }^{33}$ Sources of study and analysis:

- Tuning Europe: Reference points for the design and delivery of degree programmes in Education.

- Tuning Russia: Reference Points for the Design and Delivery of Degree Programmes in Education, 2013.

- Tuning Africa: Tuning and Harmonisation of Higher Education: The African Experience, 2014.

- Tuning Latin America: Higher Education in Latin America: reflections and perspectives on Education, 2014 + Reflections on and outlook for higher education in LA, 2007. 
possible diverse impacts of Tuning in teaching approaches. The last element investigated in this comparative analysis is some of the approaches of Tuning has developed which reflect its core philosophy and way of thinking. The most relevant issues found were: credit system; new role for teachers; consensus reaching; sharing expertise and practices; and learning outcomes assessment. Besides offering frames of interpretation, the methodology offers some key inputs for reflection, for deep analysis of teaching and learning as individual and collective phenomena. The chance to share, debate and develop a network of interconnected academic and student communities seem to be the heart of the process.

\section{Research design}

\section{III.1. Research method}

In the empirical part of the study, the researcher has opted for qualitative empirical research. Qualitative research is based on a view that social phenomena and human dilemmas (Guba and Lincoln, 1984) and the nature of cases are situational. This paper analyses the practices of teaching based on competence-based approach (CBA) from different political, institutional and cultural perspectives. The crucial factors affecting teaching practices and the contribution of the Tuning approach need to be explored and their rationale described. Therefore, the researcher chose the case study approach to address the defined research questions. Yin ${ }^{34}$ defines case study method as an empirical enquiry that investigates a contemporary phenomenon within its real-life context, especially when the boundaries between phenomenon and context are not clearly evident. As explained in the next paragraph, twelve case studies have been conducted through semi-structured interviews. Combining narratives of different case studies, a multiple case study analysi ${ }^{35}$ was chosen, since multiple cases - adequately sampled - can help in finding answers relevant for other similar settings, and can deepen understanding and explanation of the phenomena under study. For reliability and validity requirements, as Yin $^{36}$ suggests, a field guide has been created, detailing all

${ }^{34}$ Robert K. Yin, Case study research: Design and methods (3rd Ed.). (Thousand Oaks, CA: Sage, 2003).

${ }^{35}$ Robert E. Stake, Multiple Case Study Analysis. (New York: The Guildford Press, 2006).

${ }^{36}$ Robert K. Yin, "Studying phenomenon and context across sites". American Behavioral Scientist, 26, (1982): 84-100. 
the phases of the process, from research questions to information to be collected and procedures to be followed, so that other researchers could replicate the study. The documentation of the research process is described below in the figure 2 as a chain of evidence ${ }^{37}$ for possible replication. The use of multiple measures such as documents/reports and interviews as well as periodic sharing of the process and results with the researcher of Deusto International Tuning Academy (data triangulation) enhanced internal validity. ${ }^{38}$

${ }^{37}$ Kathleen Wells, "Scientific issues in the conduct of case studies". Journal of Child Psychology and Psychiatry, 28, (1987): 783-790.

${ }^{38}$ The Author expresses deep thankfulness to Dr. Maria Yarosh from DITA for the continuous support during the scholarship, providing feedback and guidance. 

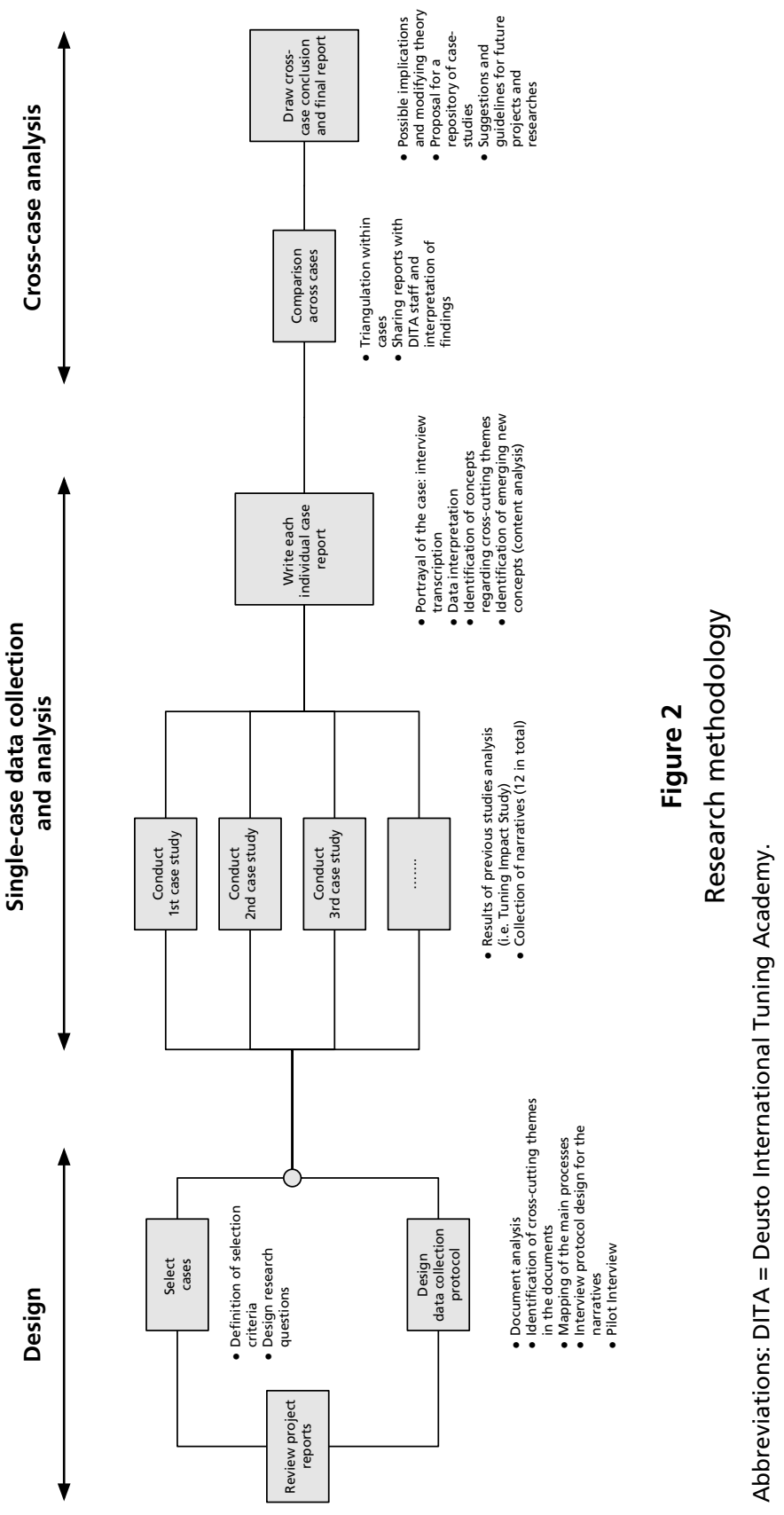


\section{III.2. Research questions and sample}

The goals of this qualitative study were:

(a) To collect descriptive information about university teaching practices according to a competence-based approach, identifying key elements.

(b) To examine the contribution of Tuning to support academic innovation in this perspective and to draft possible suggestions for future development of the methodology.

It is relevant to choose appropriate cases,$^{39}$ based on characteristics that are important for the purposes of the study, to ensure a comprehensive and correct understanding of the phenomenon investigated. The criteria for the selection of participants combined both scientific and organisational elements, as follows:

- Teachers from subject area group (SAG) "Education" (belonging to different universities in different Countries) involved in previous completed Tuning projects. As in the previous analysis of documents, the reason for choosing completed project such as Tuning Europe, Latin America, Africa and Russia was that to have a picture as complete as possible of the methodology in all its features. Moreover, the reason for choosing the subject area Education was mainly related to addressing people expert in the teaching methodology in order to deepen, both at theoretical and practical level, key aspects of implementing CBA.

- Previous or current experience in their university as a teacher (and, also, possible university managerial role), to collect real experiences and reflections on them.

- People who have possibly contributed to project publications or reports, which require further reflection and analysis on the project findings.

- SAGs coordinators have been involved as a university representative, not as group manager, since there is no aim of representativeness of each institution.

- People available for a distance interview between January 12th and February 8th (period of the scholarship).

- English speaking people or at least Spanish speaking.

${ }^{39}$ Robert E. Stake, Multiple Case Study Analysis. (New York: The Guildford Press, 2006). 
The researcher obtained information from DITA staff regarding faculty names and emails and developed an initial list of potential participants in the study by including teachers who matched the criteria. The list included 24 faculty members, who have been contacted by email. A first round of email has been sent with a subsequent reminder and nine people answered by accepting the interview. A second round of invitation emails were sent to the Spanishspeaking teachers, offering to run the interview in Spanish instead of English. Three more people offered availability, and the total number of participants was limited to twelve so that the qualitative data for the study would be manageable. found.

In Table 2 some general information of the twelve participants might be

Table 2

Participants to the study

\begin{tabular}{|l|l|c|l|}
\hline \multicolumn{1}{|c|}{ University } & \multicolumn{1}{|c|}{ Academic role } & $\begin{array}{c}\text { Previous } \\
\text { experience } \\
\text { (years) }\end{array}$ & \multicolumn{1}{|c|}{ Project attended } \\
\hline Tver State University & Rector & $20+$ & Tuning Russia \\
\hline University College Dublin & Emeritus professor & 30 & Tuning Europe \\
\hline University of Deusto & Professor & 20 & Tuning Europe \\
\hline Novgorod State University & Professor & 18 & Tuning Russia \\
\hline Eduardo Mondlane University & Dean of Faculty & 21 & Tuning Africa \\
\hline University of Namibia & Dean of Faculty & 18 & Tuning Africa \\
\hline Mogadishu University & Chief registrar & 11 & Tuning Africa \\
\hline $\begin{array}{l}\text { Tula State Lev Tolstoy } \\
\text { Pedagogical University }\end{array}$ & Dean of Faculty & 23 & Tuning Russia \\
\hline $\begin{array}{l}\text { Universidad Pedagógica } \\
\text { Nacional Francisco Morazan }\end{array}$ & Professor & 25 & Tuning Latin America \\
\hline Univerisity of Genova & $\begin{array}{l}\text { Former professor, } \\
\text { former Bologna } \\
\text { expert }\end{array}$ & 40 & Tuning Europe \\
\hline Universidad Nacional de Cuyo & Dean of Faculty & 25 & Tuning Latin America \\
\hline Universidad Núr & Dean of Faculty & 24 & Tuning Latin America \\
\hline
\end{tabular}

The interviews lasted for about one hour each on the average. They were conducted through Skype connection on an agreed timetable. Permission was sought to tape-record each conversation, and anonymous treatment of data was guaranteed. 


\section{III.3. Interview protocol}

All interviews started with a brief presentation of the research and the researcher and a request of a brief introduction of participant background information. The interview protocol has been tested in a preliminary pilot interview, and two items have been rephrased. In Table 3 below the final questions are shown:

\section{Table 3}

Interview protocol

- To what extent do you use learning outcomes and competences in designing a programme or a module?

- How do you choose the most appropriate teaching, learning and assessment strategies to allow your students to achieve the intended learning outcomes?

- What are the best methods to involve students as active actors of the learning process?

- Do you think that competence-based approach - and, in particular, the development of generic and subject-specific competences - improves students' performance and better prepares them to find a suitable job?

- Do you find it useful to have common international descriptors in the same subject areas across different universities?

- Have you been in contact with other colleagues from other institutions to discuss and share your current problems concerning competence based learning? To what extent might the higher education intercultural community be useful in that sense?

- What tool/concept/experience did you find more useful to enhance your real teaching practice during and after the participation in a Tuning project? (reflection and transfer from beliefs to practice)

- What are the major problems you have encountered in using the Tuning conceptual framework and methodological approach? How can the methodology be improved?

- How did you share the Tuning methodology with your colleagues in your University? What was their feedback?

- Which can be the contribution of Tuning methodology to teachers' professional growth and academic innovation? What aspects can be improved in order to provide meaningful teacher training for implementing competence based learning?

\section{III.4. Data analysis}

All the narratives has been recorded, transcribed and categorised; all the results were derived by conducting a content analysis of the interviews' 
transcriptions using the Atlas.ti software. The categories and dimensions emerging were compared with the previous dimensions identified in the literature and document analysis, in a dialogical approach between bottomup data collecting and a top-down data interpretation..$^{40}$ Content analysis yielded thematic categories, which enabled the researcher to have a first idea of teaching practices of implementation of CBA across different contexts and of the present and future Tuning contribution. The data on each case were first processed via a 'within-site' and then a 'cross-site' analysis to find similarities and differences between the different cases,${ }^{41}$ Each case was treated as separate offering relevant information to the phenomenon, not to represent a single university or a single Country and not with the aim of comparing different contexts. Concepts regarding cross-cutting themes highlighted above were identified as well as new emerging concepts. In the paper, the results of the 'cross-site' analysis are stressed and visually represented in some conceptual maps elaborated with Mindjet software. The discussion of findings leads to an attempt of SWOT analysis of Tuning contribution to academic innovation and suggestions for future development of the methodology.

\section{Findings}

The categories that emerged from the multiple case study are next described. Three visual interpretations of themes emerged are presented below, to answer the two research questions. It should be noted that the categories may include overlapping ideas about the meaning of teaching experience.

\section{IV.1. Competence-based approach (CBA): understanding and challenges of the approach}

Regarding CBA, codes emerged from the text were grouped into four main dimensions: understanding of the concept; implementation; impact on students; and open challenges (see figure 3).

${ }^{40}$ Paola Milani and Elena Pegoraro, L' intervista nei contesti socio-educativi: una guida pratica (Milano: Carocci, 2011)

${ }^{41}$ Matthew B Miles and A M Huberman, Qualitative Data Analysis (Thousand Oaks, CA: Sage, 1994). 


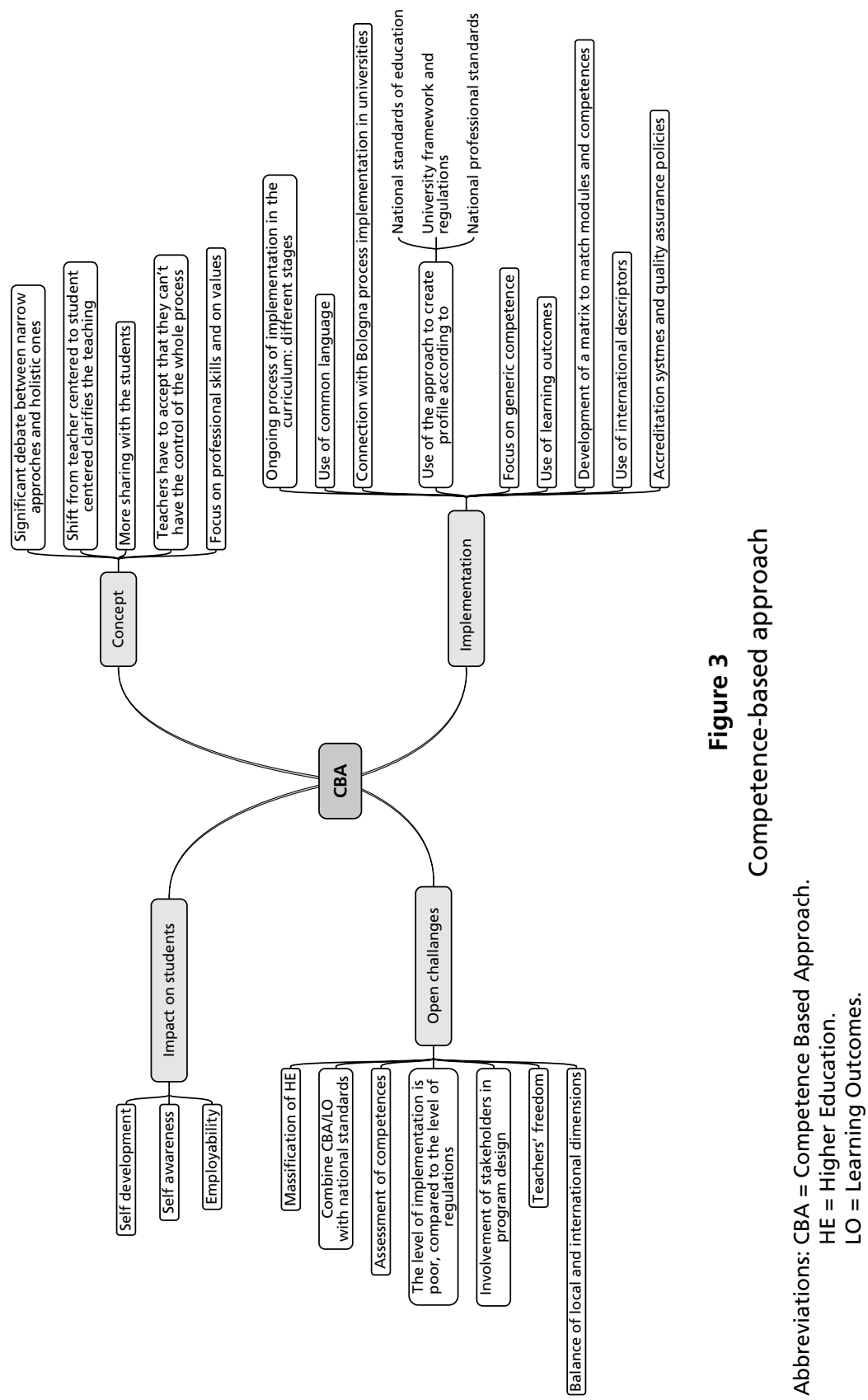

Tuning Journal for Higher Education

(C) University of Deusto. ISSN: $2340-8170$ - ISSN-e: 2386-3137. Volume 3, Issue No. 1, Novenber 2015, 19-56

doi: $10.18543 /$ tjhe-3(1)-2015pp19-56 • http://www.tuningjournal.org/ 
Participants showed interest and awareness about the main shift to the use of the concept of competence in higher education towards a more studentcentred teaching. The concept, begun with the Bologna Process, is still very debated and covers not only knowledge but also social values and professional skills of students, who are future workers and citizens. Teachers interviewed seem happy about this approach and its possible impact on students' autonomy and responsible learning. They particularly stress the fact that CBA can contribute to students' self-development, self-awareness and employability. However, they are still facing the difficulty of losing control of the teaching process as a whole. Therefore, they find it difficult to switch to this new paradigm. It is particularly interesting to see the declared level of implementation, which is not homogeneous and seems to be still an ongoing process. Many teachers underlined the relevance of having international descriptors and a system of credits, which allow transparency and mobility. As pointed out in the theoretical framework referring to Kiffer and Guy, ${ }^{42}$ competence is situational, and refers to a combination of appropriate resources used in a relevant manner in a context.Participants highlight that implementation of CBA is complex, due to the high numbers of variables to be considered, both at the course and individual level. In order to create programs oriented to the development of competences, national standards of education, university frameworks and regulations as well as national professional standards have to be considered as products of institutional, cultural, social and economic stakeholders. In this context, the concept of learning outcomes might offer clarification to determine the level of competence - as proposed by the Tuning methodology presented in the theoretical framework of the current paper - as well as other tools to make CBA real.

Many open challenges have been identified, stressing the fact that, if the CBA approach seems to be really embedded in regulations, it is sometime difficult to foster it in daily practice. Indeed, on one hand, teachers are still defending their freedom in teaching and are more focused on research, and on the other hand, massification of higher education implies growing numbers of students, not always motivated to learning, but in some cases only to obtaining a final certificate. Another major aspect perceived as challenging is the assessment of competences, namely the way in which is possible to capture and evaluate competences, as well as the balance between local dimension of higher education (including all local stakeholders) and international one.

${ }^{42}$ Kiffer Sacha and Tchibozo Guy, "Developing the Teaching Competences of Novice Faculty Members: A Review of International Literature", Policy Futures in Education 11(3) (2013): 277-289. DOI: 10.2304/pfie.2013.11.3.277 


\section{IV .2. Teaching methods according to CBA approach}

From an overall view of the competence-based approach, it was interesting to analyse texts to investigate the teaching practices used, in particular the teaching and learning activities (TLA) promoted. As shown in the theoretical framework, Entwistle ${ }^{43}$ highlights that teaching activities are influenced by teachers' conceptions of teaching, themselves influenced by departmental/university culture, academic community and validating bodies. These elements determine how course materials are organised as well as the learning environment is implemented. In consistency with this theoretical framework, participants interviewed mentioned some relevant contextual factors in choosing TLA, such as size of the class, nature and level of the students, experience of the teacher in using a certain methodology. Moreover, there seems to be a need to balance individual and organisational aspects in selecting appropriate teaching methods. In some cases there are university regulations to be followed, in order to have an harmonic integration with other colleagues teaching in the same program, in others there is still a strong emphasis on the teacher freedom to teach.

The three components identified by Baeten, Struyven and Dochy ${ }^{44}$ were used to interpret some characteristics of the TLA used by participants of the study for the development of competences (see figure 4). For the first component - the active involvement of the students - teachers mentioned the importance of involving students in doing something in order to relate learning with their future lives and jobs; the importance of letting them discover some concepts instead of explaining them and build knowledge from their expectations on the subject; the importance of using technology and tools such as learning contracts and portfolios to collect experiences and products and elaborate autonomous reflection. The second component concerns the new role of teacher - as emerged also from cross-cutting themes in the above Tuning document analysis -, who switches from being a transmitter to being a facilitator, which involves for example teamwork, cross-disciplinary projects, feedback to students, entertainment, balance between practice and theory in teaching. The learning activities as well as the assessment ones should be "authentic assignments", and that is the third

${ }^{43}$ Neol Entwistle, Concepts and conceptual frameworks underpinning the ETL project. Occasional Report 3, Enhancing teaching-learning environment (2003).

${ }^{44}$ Marlies Baeten, Katrien Struyven, Filip Dochy, "Student-centred teaching methods: Can they optimise students' approaches to learning in professional higher education?", Studies in Educational Evaluation 39 (2013): 14-22. DOI: http://dx.doi.org/10.1016/j. stueduc.2012.11.001. 


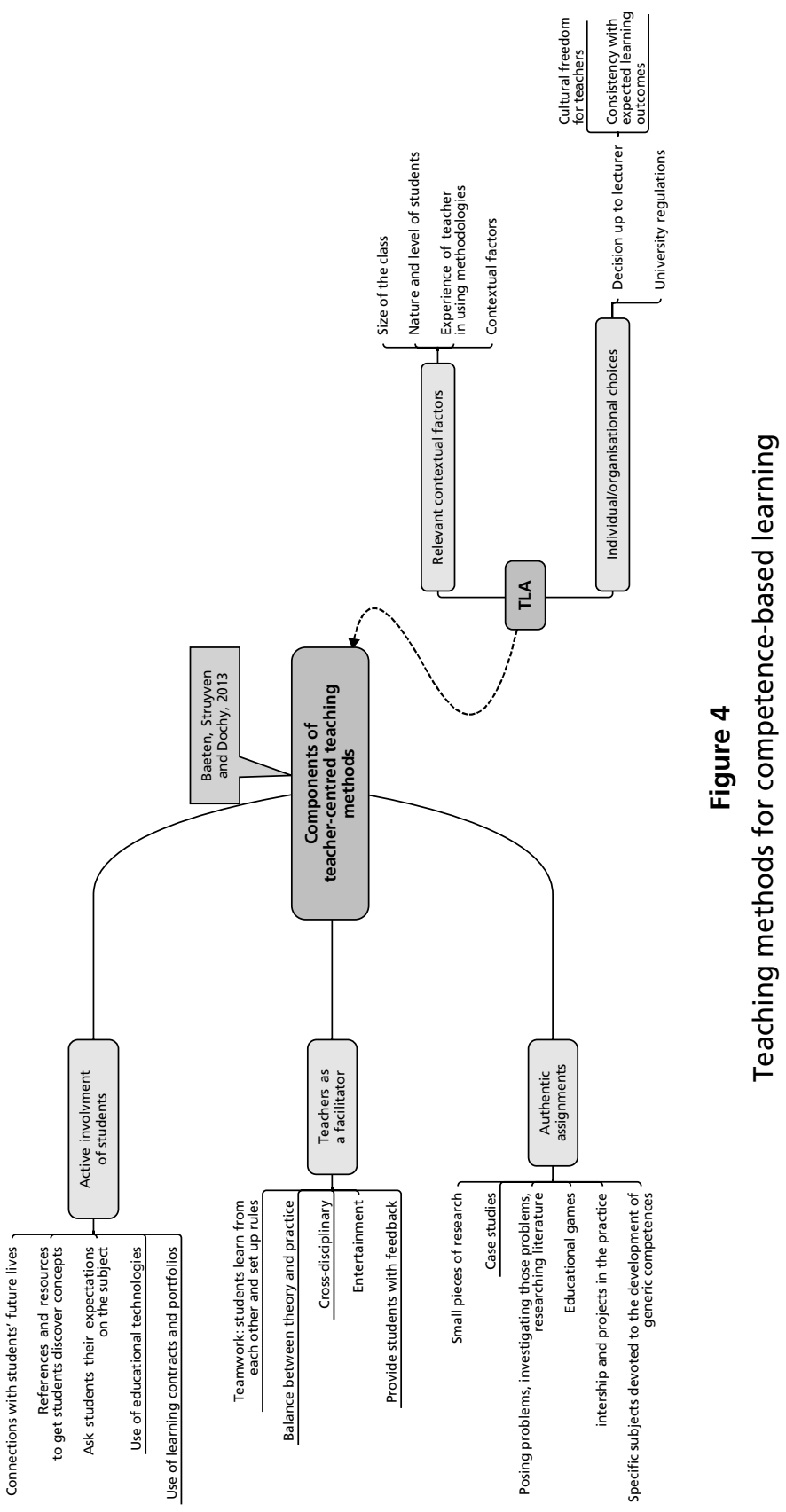


component. Participants mentioned many possible activities, for instance, small research projects, problem-solving, educational games, internships and practical case-studies, activities/subjects specifically devoted to the development of generic competences.

\section{IV.3. Tuning contribution to support academic innovation in this perspective}

The second research question of the study aimed basically at understanding and deepening the role of the Tuning methodology in the implementation of a competence-based approach to teaching. Many of the outlines emerged from the document analysis were touched and discussed and in figure 5 a visualisation of the codes grasped from the transcripts is provided.

First of all, we might distinguish between the process of Tuning, the tools considered relevant, the dissemination and the problems still open. As for the process, teachers highlight the importance of creating a dialogue with colleagues from the same area and reflect together on the same concepts, collecting possible different points of views and discussing the possible different applications in different contexts. On the same line, it seems relevant to have the chance of sharing practices, and developing conceptual frameworks to design programs, by validating the current ones with the feedback of a critical friend. The value of this mutual support is not only limited to meetings in presence during projects, but it also influences the time between meetings, as a space for review and integration of new concepts and models in the own institution. The international dimension of the Tuning approach seems to be also highly appreciated, as an opportunity to expand the view of a phenomenon and to create a network of contacts. The bottom-up approach creates an open atmosphere, with enthusiasm and commitment in starting or continuing a process of questioning the state of the art of teaching in academia and moving towards a more student-centred teaching. The value of the process reflects the usefulness of some outputs and instruments identified by participants. They found particularly relevant to learn how to have a clear structure of the process with steps and evolution. Moreover, some specific tools such as stakeholder consultation, learning guide, framework of qualifications and descriptions, metaprofile. Participants find it useful also to have examples from other projects worldwide to possibly adapt them to local contexts. If the methodology seems to be quite clear, implementation in practice in universities appears more difficult. As dissemination activities teachers reported that they have organised local meetings and presentations, also to the administration, and have tried the methodology in re-drafting curricula, involving some colleagues in local reflection. 


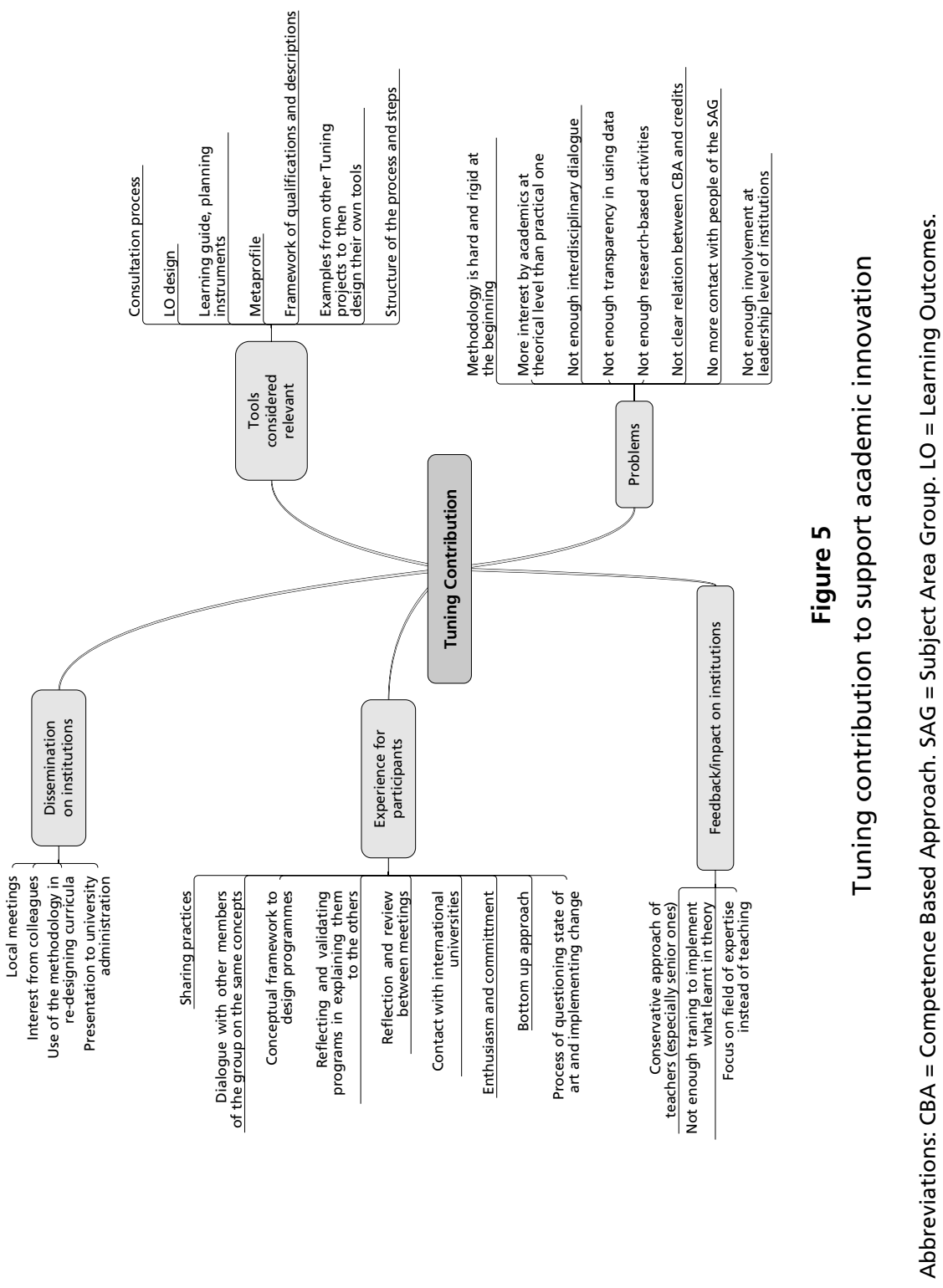


However, some issues remain problematic. In general, in the attempt of disseminating the methodology, the feedback from colleagues show some resistance. Firstly, there is probably not enough training and support for local implementation, and quite often teachers are more focused on research on their field rather than on teaching. Secondly institutional change is never an easy task. Therefore, there is a general tendency to maintain the status quo since it is known and less risky and time consuming. Some teachers highlight the rigidity of the methodology, especially at the start of each project, with some unclear relations between concepts (such as between competence and credits). The use of Subject Area Group (SAG) is interesting but does not allow interdisciplinary dialogue, which might also be enriching; some work across SAGs may allow sharing of different perspectives. It is in any case difficult to maintain contacts with colleagues at the end of the projects attended. Moreover, teachers participating in these projects might not have all the same positions and roles within their university, therefore they may not have the leadership of implementing real changes at institutional level, but only at individual level. Some would like to enhance transparency in using data collected as well as clear selection criteria or call for joint projects.

As a last point, they miss the promotion of some research-based activity related to their work on Tuning that some of them would be interested in carrying out to better integrate their research outputs with Tuning.

To summarize findings on the Tuning methodology's contribution to competence-based approach and appropriate teaching and learning activities, a synthesis is proposed below through a SWOT analysis. The SWOT is not aimed to be exhaustive, but to give an overview of some key strengths, weaknesses, opportunities and threats identified in the multiple-case study that might be useful for improvement and development:

- STRENGTHS: common reference framework, important and useful tools (i.e. templates; profiles; teaching and learning methodologies), experience with colleagues, development of reflection, international dimension, enthusiasm, sharing practices.

- WEAKNESSES: some rigidity of the methodology, lack in the implementation of CBA approach in teaching practices (in particular assessment tools), difficulty to maintain contact with colleagues, need of more research based activities.

- OPPORTUNITIES: more involvement of leadership level in university and professions, interdisciplinary dimensions, local training, online resources, database of examples, research activities, more dialogue with existing network of HE and staff development. 
- THREATS: conservative approach of academics, risk of achievement of theoretical but not practical level, risk of limited impact.

\section{Discussion}

The key themes emerging from this analysis and their possible implications are discussed below. Suggestions and guidelines for future projects, training and researches of the Tuning Academy are provided for possible implementation. The crucial relationship between teaching, learning and research ${ }^{45}$ as mentioned in the theoretical framework, emerges from this study. The teachers interviewed work in the area of Education, so they believe it is important to enhance research opportunities upon teaching practices. In the table 4 below some ideas collected during the interviews are summarised and framed within some already existing international practices. On one hand, participants are willing to undertake some research on their own teaching, such as: scholarship of teaching and learning; ${ }^{46}$ or joint publications/presentations with other Tuning colleagues; or grants to visit other advanced institutions. On the other hand, they would be interested in having some research database and tools as a powerful resource on the new trends and common issues in teacher training and on frontline academic innovative practices worldwide. A further connection with international networks of higher education might be helpful, to establish connections and scientific collaborations.

In line with a more integrated approach that considers theory and practice as part of the same process, some ideas for training are also provided that Tuning Academy might consider for the future implementation. From the participants' comments, further training is needed. Educational technologies might be relevant tools for this implementation. Moocs and eLearning initiatives can offer resources and support for distance and foster community building between professionals. Moreover, the creation of a well-trained

${ }^{45}$ Marianne Bauer and Mary Henkel, M, "Responses of Academe to Quality Reforms in Higher Education: A Comparative Study of England and Sweden”, Tertiary Education and Management, 3 (3) (1997): 211-228. DOI: 10.1007/BF02679385.

46 The Scholarship of Teaching and Learning (SoTL) is an emerging movement of scholarly thought and action that draws on the reciprocal relationship between teaching and learning at the post-secondary level (Boyer, 1990). An important goal of SoTL is to enhance and augment learning amongst and between individual learners by investigating the many features of discipline specific expertise and best pedagogical practice (McKinney, 2006). For more info see: http://www.stlhe.ca/sotl/ 


\section{Table 4}

Suggestions for the Tuning research, training and projects

\begin{tabular}{|c|c|}
\hline RESEARCH & $\begin{array}{l}\text { - Scholarship of teaching and learning (SoTL) for every subject } \\
\text { - More focus on joint publications and presentations at } \\
\text { international conferences } \\
\text { - Call for grants and visits to advanced universities } \\
\text { - Open access database of data collected (including the data } \\
\text { analysis) } \\
\text { - Open access repository of case studies } \\
\text { - Further contact with national study centres, national and } \\
\text { international networks, and with local units at faculty for } \\
\text { educational development } \\
\text { - Analysis of educational development initiatives worldwide and } \\
\text { intercept trends }\end{array}$ \\
\hline TRAINING & $\begin{array}{l}\text { - Online Mooc: theories, examples from other universities, } \\
\text { contact people and coordination of local initiatives } \\
\text { - Consultation service on specific problems } \\
\text { - Visit by experts to receive some external feedback } \\
\text { - Group of Tuning consultants across the world accredited to } \\
\text { provide training (maybe from Education) }\end{array}$ \\
\hline PROJECTS & $\begin{array}{l}\text { - Protocols of transparency in selection, sharing data and results } \\
\text { - Practical labs during the projects, to avoid the risk of only } \\
\text { theoretical perspectives } \\
\text { - Interdisciplinarity across SAG } \\
\text { - Assessment of competences: tools and examples } \\
\text { - Methods of building partnership with students: increasing } \\
\text { engagement } \\
\text { - Development of validated tools for local need analysis in } \\
\text { universities (for students and teachers) } \\
\text { - Involving in projects both teachers and leaders in university } \\
\text { - Call for paper for practices sharing } \\
\text { - Establishment of a more structured Tuning network for } \\
\text { sharing and connecting people, faculty learning community }\end{array}$ \\
\hline
\end{tabular}

group of Tuning consultants across the world could be a powerful resource to offer consultations and training especially in universities that require it. Since Tuning addressed the needs of universities and academics for fifteen years, by promoting a bottom-up approach through several projects, some suggestions for future projects are also provided. Participants showed more interest in possible projects focussing on implementation, including tools for assessment of competences, practical laboratories, methods for engaging students in the learning process as a partner to the teaching process. It might be interesting to involve people with a similar role in their own institution in 
projects, to allow a better sharing of perspectives and possible future implementation within their universities. The idea of sharing practices seems to be relevant, and possible improvement of it can be considered: for example, the creation of a call for practice sharing with a possible publication of them or the development of a structured network and faculty learning communities across universities might be a powerful resource.

\section{Conclusions}

This paper has investigated the Tuning contribution to academic innovation through the collection of case studies among some Tuning projects, highlighting methods and tools to implement successful and innovative approaches to learning, teaching, and assessment appropriate for competence-based approach. The literature shows the complexity of the teaching phenomenon and the several variables that need to be considered towards a professional identity which integrates teaching, learning and research Active involvement of students, teacher as a facilitator and authentic assignments appear as key features. ${ }^{47}$ From multiple case studies emerged that there seems to be a good understanding of the student centred approach, but still open challenges in its implementation, due to internal and external factors. On the first side, teachers' freedom as well as lack of pedagogical training represent internal obstacles that requires attention and further investment. At the same time, on the second side, it is not easy to face a new era of higher education system, new required balance of local and international dimensions, new and more demanding students with often the same teaching resources.

The Tuning contribution appears as a relevant tool to support this paradigm shift, however the research highlighted also some critical aspects. Tuning appears indeed as a powerful experience for participants in terms of opportunity to stay in contact with colleagues and learn new ways/tools of questioning their own practice, but some problems still appear in terms of implementation and impact on the institutions. New ideas for future strategies for supporting the improvement of teaching activities have been provided, interpreting needs emerged from case studies and developing them in three perspectives. The first one is a strong research orientation, with the possibility of developing scholarly-based activities and evidence-based good practices

${ }^{47}$ Marlies Baeten, Katrien Struyven, Filip Dochy (2013), Student-centred teaching methods: Can they optimise students' approaches to learning in professional higher education? Studies in Educational Evaluation 39 (2013) 14-22. 
useful to circulate and enrich teachers' learning. The second is the tailoring of training processes to promote the change of the teaching practice, with a major focus on the use of online environments and practical resources such as videos, teaching examples, tips and databases. The third is a possible development of specific projects that can address specific themes, by deepening them from a theoretical, methodological and practical point of view. This integrated vision among teaching, learning and research may represent for the Tuning community as well as for the academic community in general a new and more systemic and effective approach to foster academic innovation and students learning.

\section{Limitations of the study and possible further development}

The research offers a first overview and reflection on competence-based learning and related teaching and learning practices across different Tuning projects in the area of Education. Findings show different understanding of the CBA, level of implementation and open challenges. Due to the qualitative design of the study, results cannot be generalized, and intercultural dimensions should be carefully considered. The number of teachers interviewed was limited to twelve because the organisation of each interview took quite a lot of time considering different times, languages, availabilities, internet connections. However, a replication of this study, focusing on other subjects (preferably from a scientific field), would be particularly interesting to widen the sample and continue investigating deeply the phenomenon, in order to expand understanding and confirm/disconfirm findings.

Moreover, since comparisons are not possible, it might be interesting in long-term future also to carry out a quantitative research, by developing and validating an instrument based on qualitative results. This may be a relevant tool for teachers' need analysis and for possible future development of new projects and training activities. Further integration with faculty professional development models, such as scholarship of teaching and learning ${ }^{48}$ and creation of (online) faculty learning communities ${ }^{49}$ to start up a shared repository of teaching practices, might lead to further researches and reflections on possible applications.

${ }^{48}$ El Boyer, Scholarship Reconsidered: Priorities of the Professoriate, (Princeton: Princeton University Press, The Carnegie Foundation for the Advancement of Teaching, 1990).

49 Milton D. Cox, "Introduction to faculty learning communities". New Directions for Teaching and Learning, 97 (San Francisco: Wiley Periodicals, Inc, 2004): 5-23. 


\section{Bibliography}

Baeten Marlies, Struyven Katrien, and Dochy Filip. "Student-centred teaching methods: Can they optimise students' approaches to learning in professional higher education?". Studies in Educational Evaluation 39 (2013): 14-22. DOI: http://dx.doi.org/10.1016/j.stueduc.2012.11.001.

Bauer Marianne and Henkel Mary, "Responses of Academe to Quality Reforms in Higher Education: A Comparative Study of England and Sweden", Tertiary Education and Management, 3 (3) (1997): 211-228. DOI: 10.1007/BF02679385.

Biggs John and Tang Catherine, Teaching for Quality Learning. New York, McGraw-Hill, 2007.

Bligh Donald, What's the Use of Lectures? London: Jossey-Bass, 2000.

Boyer El, Scholarship Reconsidered: Priorities of the Professoriate. Princeton: Princeton University Press, The Carnegie Foundation for the Advancement of Teaching, 1990.

Coulet Jean-Claude, "La notion de compétence: un modèle pour décrire, évaluer et développer les competences", Le travail humain, 74(1) (2011): 1-30. DOI: http://dx.doi.org/10.3917/th.741.0001

Cox Milton D., "Introduction to faculty learning communities". New Directions for Teaching and Learning, 97 (San Francisco: Wiley Periodicals, Inc, 2004): 5-23.

Delanty Gerard, "The university and modernity: A history of the present" In The Virtual University? Knowledge, markets and management, ed. Robins K, Webster F (Oxford: Oxford University Press 2002), 31-48.

Entwistle Neol, Concepts and conceptual frameworks underpinning the ETL project. Occasional Report 3, Enhancing teaching-learning environment (2003).

Etzkowitz Henry and Viale Riccardo, "Polyvalent knowledge and the entrepreneurial university: A third academic revolution?" Critical Sociology 36(4) (2010): 595609. DOI: $10.1177 / 0896920510365921$.

Etzkowitz Henry, Ranga Marina, Dzisah James, "Whither the university? The Novum Trivium and the transition from industrial to knowledge society", Social Science Information 51(2) (2012): 143-164. DOI: 10.1177/0539018412437099.

Europan Commission. The Bologna Process - reforming universities in the next decade, 22 April 2009. Available at: http://europa.eu/rapid/pressReleasesAction. do? reference $=\mathrm{IP} / 09 / 615 \&$ format $=$ HTML\&aged $=0 \&$ language $=E N \&=$ guiLangu age $=$ fr.

Gibbons Michael, Limoges Camille, Nowotny Helga, Schwartzman Simon, Scott Peter, Trow Martin. The New Production of Knowledge. (London: Sage Publications, 1994).

Gibbs Graham, "The Relationship between Quality in Research and Quality in Teaching", Quality in Higher Education, 1(2) (1995): 147-157. DOI: 10.1080/1353832950010205.

, 53 Powerful Ideas All Teachers Should Know About, idea n. 20, Ocober 2014, available at: http://www.seda.ac.uk/53-powerful-ideas/ 
González Julia and Wagenaar Robert, TUNING Educational Structures in Europe II. Universities' contribution to the Bologna Process. Final report Project Phase II. Universidad de Deusto / Universiteit Groningen, 2005.

Gow Lyn and Kember David, "Conceptions of teaching and their relationship to student learning," British Journal of Educational Psychology 63(1993): 20-33.

Kember David, "Teaching beliefs and their impact on students' approach to learning," in Teaching and Learning in Higher Education, ed. Barry Dart and Gillian Boulton-Lewis, 1-25 (Camberwell, Australia: Australian Council for Educational Research, 1998).

Le Boterf Guy, De la compétence: essai sur un attracteur étrange. (Paris: Editions d'Organisation, 1994).

Lee Jenny J, "The shaping of the departmental culture: Measuring the relative influences of the institution and discipline", Journal of Higher Education Policy and Management 29 (1) (2007): 41-55, DOI: 10.1080/13600800601175771.

Lokhoff, Jenneke, Bas Wegewijs, Katja Durkin, Robert Wagenaar, Julia González, Ann Katherine Isaacs, Luigi $\mathrm{F}$ Donà dalle Rose, and Mary Gobbi. A Guide to Formulating Degree Programme Profiles. Bilbao, Groningen, and The Hague: Universidad de Deusto, 2010.

Milani Paola and Pegoraro Elena, L'intervista nei contesti socio-educativi: una guida pratica (Milano: Carocci, 2011).

Miles Matthew B and Huberman A M, Qualitative Data Analysis, (Thousand Oaks, CA: Sage, 1994).

Sacha Kiffer and Guy Tchibozo, "Developing the Teaching Competences of Novice Faculty Members: A Review of International Literature", Policy Futures in Education 11(3) (2013): 277-289. DOI: 10.2304/pfie.2013.11.3.277.

Samuelowicz Katherine and Bain John D., "Conceptions of teaching held by academic teachers", Higher Education, 24, (1992): 93-111.

Shulman Lee S., "Knowledge and teaching: Foundations of the new reform". Harvard Educational Review 57(1) (1987): 1-22.

Slavin Robert E., "Cooperative learning". Review of Educational Research 50(2) (1980): 315-342. DOI: 10.3102/00346543050002315.

Stake Robert E., Multiple Case Study Analysis. (New York: The Guildford Press, 2006).

Stoof Angela, Martens Rob L., van Merriënboer Jeroen J. G, Bastiaens Theo J., "The Boundary Approach of Competence: A Constructivist Aid for Understanding and Using the Concept of Competence", Human Resource Development Review 1 (3) /2002): 345-365. DOI: 10.1177/1534484302013005.

Van der Klink Marcel, Boon Jo, Schlusmans Kathleen, "Designing and Implementing Views on Competencies". In Competencies in Organizational E-Learning: Concepts and Tools, ed. Miguel A. Sicilia (Idea Group, 2007).

Vermunt Jan D. and Verloop Nico, "Congruence and friction between learning and teaching”. Learning and Instruction, 9, (1999): 257-280. DOI: http://dx.doi. org/10.1016/S0959-4752(98)00028-0. 
Von Glaserfeld Ernst, "A constructivist approach to teaching” In Constructivism in education (pp). Eds L. Steffe \& J. Gale (Eds.) (Hillsdale, NJ: Lawrence Erlbaum, 1995), 369-384.

Wagenaar Robert, "Competences and learning outcomes: a panacea for understanding the (new) role of Higher Education?", Tuning Journal of Higher Education, 1(2) (2014): 279-302.

Wells Kathleen, "Scientific issues in the conduct of case studies". Journal of Child Psychology and Psychiatry, 28, (1987): 783-790.

Yin Robert K., "Studying phenomenon and context across sites". American Behavioral Scientist, 26, (1982): 84-100.

- Case study research: Design and methods (3rd Ed.). (Thousand Oaks, CA: Sage, 2003).

Zepke Nick, "Threshold concepts and student engagement: Revisiting pedagogical content knowledge", Active Learning in Higher Education 14(2) (2013). DOI: 97-107, DOI: $10.1177 / 1469787413481127$.

\section{About the Author}

ANNA SERBATI earned a PhD (2010-2013) in Educational Sciences at the University of Padova. Her field of specialization is the research on adult learning with a specific focus on processes and tools for the assessment and certification of competences acquired in formal, non-formal and informal contexts. In this area of research, she published a monograph as well as articles and book chapters and she presented paper in international conferences. She currently is post-doc research fellow at the Department of Philosophy, Sociology, Education and Applied Psychology at the University of Padova, where she also teaches assessment of competences to master students. Her current research interests are academic innovation, teachers training, pedagogical thinking, teachers' collaborative reflection and she leads a research on teachers' professional development and academic educational innovation. Anna collaborates also with the Tuning Academy since 2011 in several projects on competence-based learning.

\section{Copyright}

Copyright for this article is retained by the Publisher. It is an Open Access material that is free for download, distribution, and or reuse in any medium only for non-commercial purposes; provided any applicable legislation is respected, the original work is properly cited, and any changes to the original are clearly indicated. 